\title{
NERVE ROOTS AND NUCLEAR GROUPS IN THE SPINAL CORD OF THE PIGEON
}

\author{
JOHN FRANKLIN HUBER \\ Laboratory of Comparative Neurology, Department of Anatomy, \\ University of Michigan ${ }^{ \pm}$ \\ TWHNTY-SEVEN FIGURES
}

(Accepted for publication September 21, 1935)

\section{CONTENTS}

Introduction

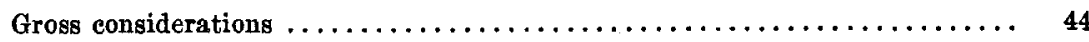

Preparation of gross specimens $\ldots \ldots \ldots \ldots \ldots \ldots \ldots \ldots \ldots \ldots \ldots \ldots, 44$

Tabulation of number of spinal nerves in pigeon and their grouping into regions, as given in the literature $\ldots \ldots \ldots \ldots \ldots \ldots \ldots \ldots \ldots$ Examination of specimens and discussion of results .............. Tabulation of spinal nerves of pigeon based on examination of specimens

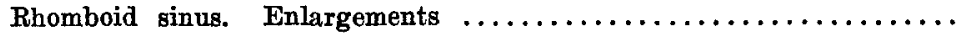

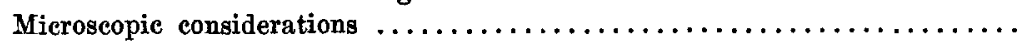

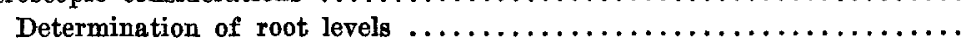

General relations of gray and white matter $\ldots \ldots \ldots \ldots \ldots \ldots \ldots \ldots$

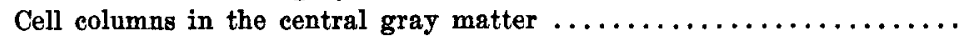

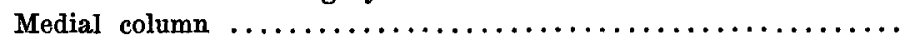

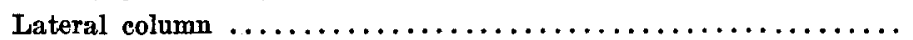

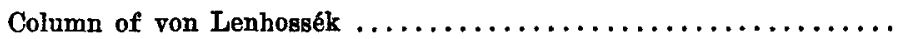

Preganglionic column (Terni) $\ldots \ldots \ldots \ldots \ldots \ldots \ldots \ldots \ldots \ldots \ldots$

Large-celled dorsal column . ..................... 65

Other cells in the central gray matter .................. 66

Peripheral gray matter-paragriseal nerve cells $\ldots \ldots \ldots \ldots \ldots \ldots \ldots .67$

Marginal paragriseal column $\ldots \ldots \ldots \ldots \ldots \ldots \ldots \ldots \ldots \ldots \ldots \ldots$

Scattered paragriseal cells $\ldots \ldots \ldots \ldots \ldots \ldots \ldots \ldots \ldots \ldots \ldots \ldots, 84$

Contents of the rhomboid sinus $\ldots \ldots \ldots \ldots \ldots \ldots \ldots \ldots \ldots \ldots \ldots \ldots$

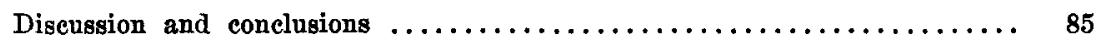

Tabulation of cell columns of pigeon's spinal cord $\ldots \ldots \ldots \ldots \ldots \ldots \ldots$. 87

A dissertation submitted in partial fulfilment of the requirements for the degree of doctor of philosophy in the University of Michigan. 
INTRODUCTION

The aim of this study is to make a complete analysis of the position and extent of all of the cell groups in the spinal cord of the pigeon. These groups were studied in both cross and frontal serial sections of the entire cord, giving an opportunity to check their appearance in different planes. Whenever possible, graphic methods of study were introduced to minimize the element of personal interpretation. For reasons given later, it has been found necessary to include a general gross description of the pigeon spinal cord and associated nerves.

I wish to take this opportunity of expressing my appreciation for being permitted to use the serial sections which have formed the basis for a greater portion of this study and of thanking Dr. Elizabeth Crosby for her part in the supervision of the work and for her most generous help. I also wish to express my very sincere feeling that it was a rare privilege to have been able to carry out this study under the guidance and supervision of the late Dr. G. Carl Huber.

\section{GROSS CONSIDERATIONS}

Of the existing gross descriptions of the brain, spinal cord and emerging cranial and spinal nerves of the pigeon which were found, many are meager and differ widely in details of account and not one is accompanied by a careful, complete and accurate figure. Therefore it was necessary to describe first the gross picture of the cord and spinal nerves in order to obtain a basis for definite location of the microscopic structures of special interest. An idea of the necessity for the standardization of the information about the spinal nerves of the pigeon can be obtained from the tabulation of material in the literature on this subject (table 1).

\section{Preparation of gross specimens}

Studies were attempted by usual dissection methods but it was found much more satisfactory to make use of a method which has been used in this laboratory for several decades 
for the purpose of making rapid isolation of the central nervous system and attached peripheral nerves in smaller mammals and in essential consists of a controlled maceration in nitric acid. This method of preparing gross specimens of the nervous system is dependent on the fact that nitric acid, in correct concentration, decalcifies the bone and softens the

TABLE 1

Number of spinal nerves in pigeon and their allocation to regions, as given in the literature

\begin{tabular}{|c|c|c|c|c|c|c|}
\hline AUTHOR & OERV, & THOR. & LUMB & sAo. & coco. & TOTAL \\
\hline $\begin{array}{l}\text { Packard, A. S. } \\
(1879, \text { p. 529) }\end{array}$ & 12 & $\cdots$ & $\cdots$ & $\cdots$ & $\cdots$ & $\cdots$ \\
\hline $\begin{array}{l}\text { Martin and Moale } \\
(1888, \text { p. } 130)\end{array}$ & 15 & 5 & 3 & 4 & $11^{x}$ & 38 \\
\hline $\begin{array}{l}\text { Ariëns Kappers, C. U. } \\
\quad(' 20, \text { p. 167) }\end{array}$ & 12 & 8 & \multicolumn{2}{|c|}{12 lumbo-sacral } & 6 & 38 \\
\hline $\begin{array}{l}\text { Papez, J. W. } \\
\text { ('29, p. 412) }\end{array}$ & 12 & 8 & \multicolumn{2}{|c|}{12 lumbo-sacral } & 6 & 38 \\
\hline $\begin{array}{l}\text { Parker, T. J.3 } \\
\quad(1884, \text { p. } 183)\end{array}$ & 14 or 15 & 5 & 2 or 3 & 3 or 4 & About 12 & $36-39$ \\
\hline $\begin{array}{l}\text { Shufeldt, R. W.' } \\
\text { ('01, p. 496) }\end{array}$ & 15 & 4 & (None) & 14 & 6 & 39 \\
\hline $\begin{array}{l}\text { Martin, R.' } \\
\quad\left({ }^{2} 04 \text {, p. } 49\right)\end{array}$ & 15 & 4 & \multicolumn{2}{|c|}{$\begin{array}{c}\text { 13-17 } \\
\text { (Columbiformes) }\end{array}$} & 5 & $37-41$ \\
\hline $\begin{array}{l}\text { Parker and Haswell } \\
\quad(10, \text { p. 387) }\end{array}$ & 15 & 5 or 6 & 5 or 6 & 2 & 11 & $38-40$ \\
\hline
\end{tabular}

Vertebral count given and these figures based on the assumption that there is one more cervical nerve than cervical vertebrae and that the nerve count would correspond with the vertebral count in other regions.

muscle and connective tissue but in a measure acts as a fixing agent for the nervous tissue.

The procedure as carried through, in this specific application, can be outlined as follows: 1) pigeon killed by ether; 2) skinned; 3) sternum, attached muscles and upper extremities removed by cutting the ribs on both sides about $1 \mathrm{~cm}$. from the vertebral column and releasing the scapula by severing its muscle attachments to the trunk, the brachial 
plexus and accompanying vessels having been cut just distal to the head of the humerus; 4) viscera all removed from the thoraco-abdominal cavity; 5) lower extremities removed and pelvis trimmed to approximately $1 \mathrm{~cm}$. from the vertebral column; 6) musculature cleaned from the tail; 7) eyes removed; 8) specimen tied straight on its back on a narrow glass plate with waxed linen thread; one thread around upper bill, one at the lower part of the neck and one at the pelvis; 9 ) the whole submerged in $10 \%$ nitric acid for 24 to 30 hours and then for another 24 to 30 hours in the same acid solution with sufficient nitric acid added to make it a $20 \%$ solution; 10) specimen removed from acid and placed in water, and the macerated and sof tened tissue carefully teased and pulled away from the nervous system, leaving the brain, cord, emerging nerves and the sympathetic trunk in their natural relations to each other.

\section{Examination of specimens and discussion of results}

From the examination of specimens thus prepared, such as that in figure 1, in conjunction with dissected specimens, it was learned that there are thirty-nine pairs of spinal nerves in the pigeon (Columba livia domestica), calling the nerve emerging between the atlas and the occipital bone the first spinal nerve and finding the last one, a very small one which might be questioned, between the last free caudal vertebra and the pygostyle.

The counting of the spinal nerves, when specimens are at hand, is a relatively simple matter but when one attempts to allocate the nerves to cervical, thoracic, lumbar, sacral and coccygeal regions the problem is much more complicated, because there is a distinct lack of generally used criteria which seem in any way meaning-full from a comparative neurological viewpoint.

The groupings into regions which have been carried out by previous authors for the most part have been based upon the regions as determined by certain habits in skeletal description. However, there exists in the literature (table 1, p. 45) even less agreement as to the division into regions 


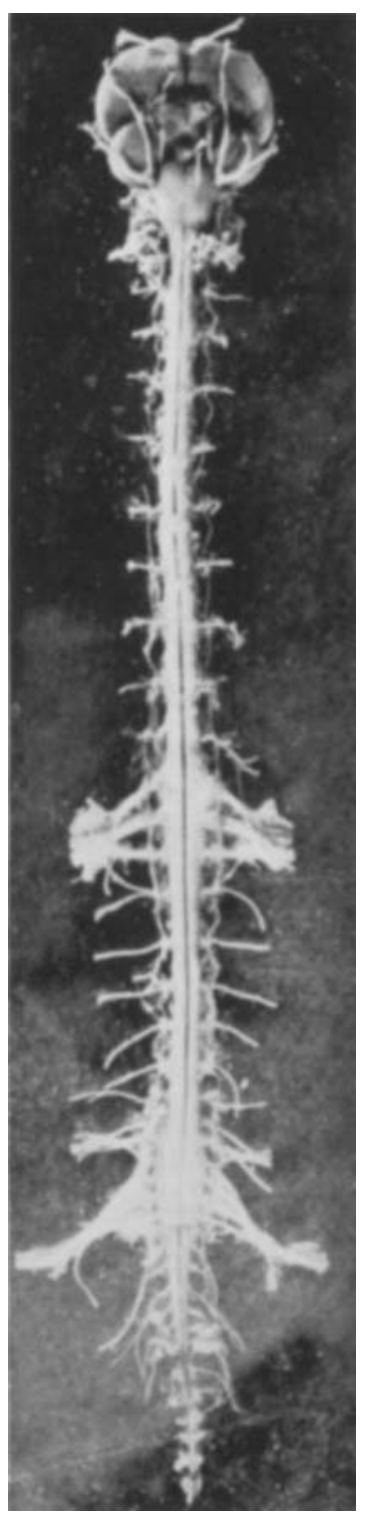

A

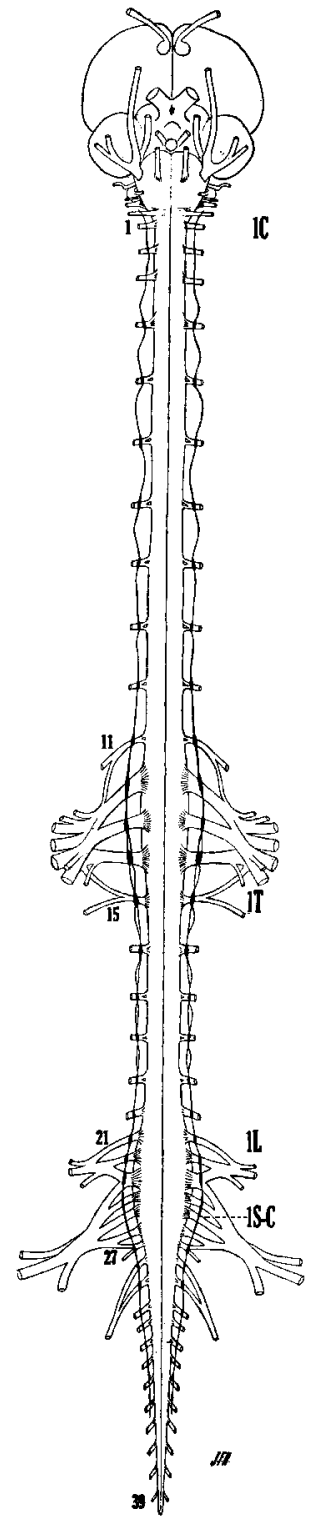

B

Fig. 1 Central nervous system, emerging cranial and spinal nerves and sympathetic trunk of the pigeon. Actual size. A, photograph of specimen. B, drawing to scale of same specimen; numbers indicate spinal nerve numbers; $1 \mathrm{C}$, cervical 1 ; $1 \mathrm{~T}$, thoracic 1 ; $1 \mathrm{~L}$, lumbar 1 ; $1 \mathrm{~S}-\mathrm{C}$, sacro-coceygeal 1. 
than as to the total number of nerves and the fact that the basis of division is not stated in many cases adds to the confusion. Due to this fact it seems preferable simply to number the nerves from 1 to 39, and refer to them by number, until some division into regions is generally accepted.

The obvious objection to this procedure is, of course, that one must have a figure at hand or in mind to know in what general region a certain nerve would fall. By reason of this objection a method of division into regions is suggested which may prove acceptable since it admits of homologizing with other vertebrate forms, including man. The formation of the major plexuses by the spinal nerves in the pigeon is compared to the formation of those by the spinal nerves in man and the similarities noted, combined with certain skeletal features, form the basis of the division into regions.

$A$ s is generally accepted, the nerve emerging between the atlas and occipital bone is called the first cervical nerve. An indication as to which should be called the last cervical nerve can be obtained from the make-up of the brachial plexus. In the eight specimens examined it was found that spinal nerves 12, 13 and 14, together with a branch from 11 and one from 15 , onter into the formation of this plexus. (The work of Fürbringer, quoted by Gadow (1891; p. 138 and plate XLIV, fig's. 9, 10 and 11), indicates that there are variations from this pattern as would be expected, since one sees many variations in the plexuses in human dissections.) The portion of nerve 15 not entering into the formation of the brachial plexus runs forward under the first rib $^{2}$ which enters into the forma-

\footnotetext{
"It may be recalled that in the pigeon there are seven ribs, articulating with the thirteenth to the nineteenth vertebrae. The one attached to the thirteenth vertebra is short and unlike the other six, which are quite similar to each other and definitely enter into the formation of the thoracic cage. Of these, the one attached to the fourteenth vertebra has no sternal attachment, while the others are provided with distinet stemal ribs, although the last often attaches to the $\mathrm{rib}$ preceding rather than directly to the sternum. Since these six ribs are similar and definitely form the thoracic wall, they all may be designated thoracic ribs in spite of the rather generally accepted precedent that a thoracic rib should have a sternal attachment (Huxley, 1872; Reynolds, '13; Kingsley, '25). Such an interpretation is consistent with the fact that the inferior human ribs (at least 11 and 12) have no sternal attachment and yet are termed thoracie ribs.
} 
tion of the thorax, and is, therefore, the first intercostal nerve. In a similar fashion the last nerve contributing definitely to the brachial plexus in man, which is the first thoracic nerve, has one portion continuing forward as the first intercostal nerve (fig. 2). On the basis of this homology spinal nerve 15 of the pigeon is called the first thoracic nerve and the first fourteen nerves are grouped as cervical.

Nerves 15 to 20 are grouped as thoracic because each one respectively exits below a vertebra to which a thoracic rib (as indicated above) is attached.

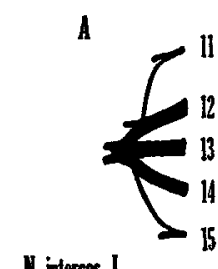

I. intercos. I

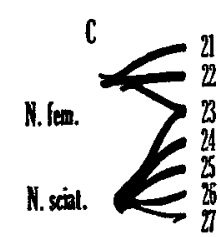

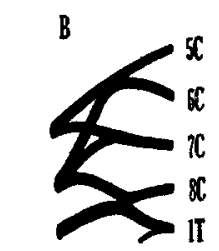

N. inleres. I

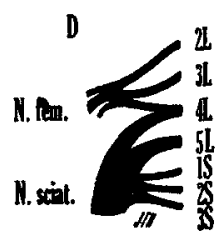

Fig. 2 Comparison of major plexuses of the pigeon with those of man. A, diagrammatic representation of pigeon's brachial plexus. B, conventional diagram of human brachial plexus. C, diagrammatic representation of pigeon's lumbo-sacral plexus. $\mathrm{D}$, conventional diagram of human lumbo-sacral plexus. The numbers in $A$ and $C$ are the spinal nerve numbers and the numbers and letters in $B$ and $D$ designate the nerves as to regions. $N$. fem., femoral nerve; N. intercos. I, first intercostal nerve; N. sciat., sciatie nerve.

The first lumbar nerve is then nerve 21 and the lumbosacral plexus is used to determine the division between the lumbar and sacral regions. Nerves $21,22,23,24,25,26$ and part of 27 enter into the formation of the lumbo-sacral plexus, 21,22 and part of 23 contributing to the femoral nerve and the remainder of 23 , with $24,25,26$ and part of 27 contributing to the formation of the sciatic nerve. As shown in figure 2 this general pattern of the make-up of the femoral and sciatic 
nerves is very similar to that in man. That is, in man the femoral nerve receives contributions from lumbar 2,3 and part of lumbar 4 and the sciatic nerve receives contributions from the other part of 4 and 5 and from sacral 1,2 and part of 3 . Therefore, nerve 25 in the pigeon corresponds to sacral 1 in man. Nerves $21,22,23,24$ then are the lumbar nerves. The sacral region begins with nerve 25 but apparently there is no definite criterion to use in separating the sacral from the coccygeal nerves, therefore it seems advisable to group nerves 25 to 39 as sacro-coccygeal. In this connection reference may be made to the possibility of dividing the sacral and coccygeal regions on the basis of the nerves supplying primarily the cloacal region (sacral) and the nerves supplying primarily the structures on the tail (coccygeal). If this rough basis were used, spinal nerve 32 would be called the last sacral nerve, making 25 through 32 sacral (8 sacral nerves) and 33 through 39 coccygeal (7 coccygeal nerves).

The sacral and coccygeal (or caudal) nerves also could be delimited by designating those nerves which pass out below free caudal vertebrae the coceygeal (or caudal) nerves. Spinal nerve 33 exits between the synsacrum and the first free caudal vertebra so that 34 is the first nerve below a free caudal vertebra, which would make 25 through 33 sacral (9 sacral nerves) and 34 through 39 coccygeal (6 coccygeal nerves). It is interesting to note that this latter division might be said to correspond to the situation in man because the last nerve which goes to the cloacal region (corresponding in general to the perineum in man) is 32 or the next to the last sacral nerve, which is also true in man where sacral 4 (the next to the last sacral) is the lowest nerve to the perineum.

No attempt is made here to decide concerning a possible division into sacral and coccygeal regions, since such a separation does not seem to be of value in the consideration of cell groups, this separation coming, as it would, caudal to the region of origin of the nerves to the lower extremity. 
The spinal nerves of the pigeon (Columba livia domestica), numbered 1 to 39 , can therefore be grouped into regions in the following manner:

TABLE 2

\begin{tabular}{l|c|c}
\hline \multicolumn{1}{c|}{ REGION } & NUMBER OF NERVES IN REGION & SPINAL NGRVES \\
\hline Cervical & 14 & 1 to 14 \\
Thoracic & 6 & 15 to 20 \\
Lumbar & 4 & 21 to 24 \\
Sacro-coccygeal & 15 & 25 to 39 \\
\hline
\end{tabular}

\section{Rhomboid sinus. Enlargements}

No gross consideration of the pigeon's spinal cord could be presented without mentioning the so-called rhomboid sinus, which especially characterizes the spinal cords of birds. This fusiform fossa is filled with a jelly-like substance and completely separates the dorsal funiculi in the lumbo-sacral region. Its extent, shape and relations to the other parts of the cord in this region are given best by means of the accompanying diagrammatic figure (fig. 3 , on next page).

Attention may also be called to the presence of cervical and lumbo-sacral enlargements, corresponding roughly to the brachial and lumbo-sacral plexuses, respectively, as shown in figure 1. It also is of interest to note that there is no cauda equina present, since the spinal cord of the pigeon reaches the entire length of the vertebral column throughout life.

\section{MICROSCOPIC CONSIDERATIONS}

The series of microscopic sections used in this study are from the Huber collection of the Laboratory of Comparative Neurology, University of Michigan. They include both longitudinal and cross section series of pigeon spinal cord, and of embryonic chick cord, certain of which were prepared by the trichloracetic-mercury-alcohol fixation method and stained with toluidin blue (Huber, '27) and the others prepared according to Huber's modification of the Ranson pyridine-silver method (Huber and Guild, '13). 


\section{Determination of root levels}

Of the sections of pigeon cord stained with toluidin blue, one longitudinal series (E) and one transverse series (B) were completely analyzed in regard to the cell groups and cell types at all levels and in these series the exact location of

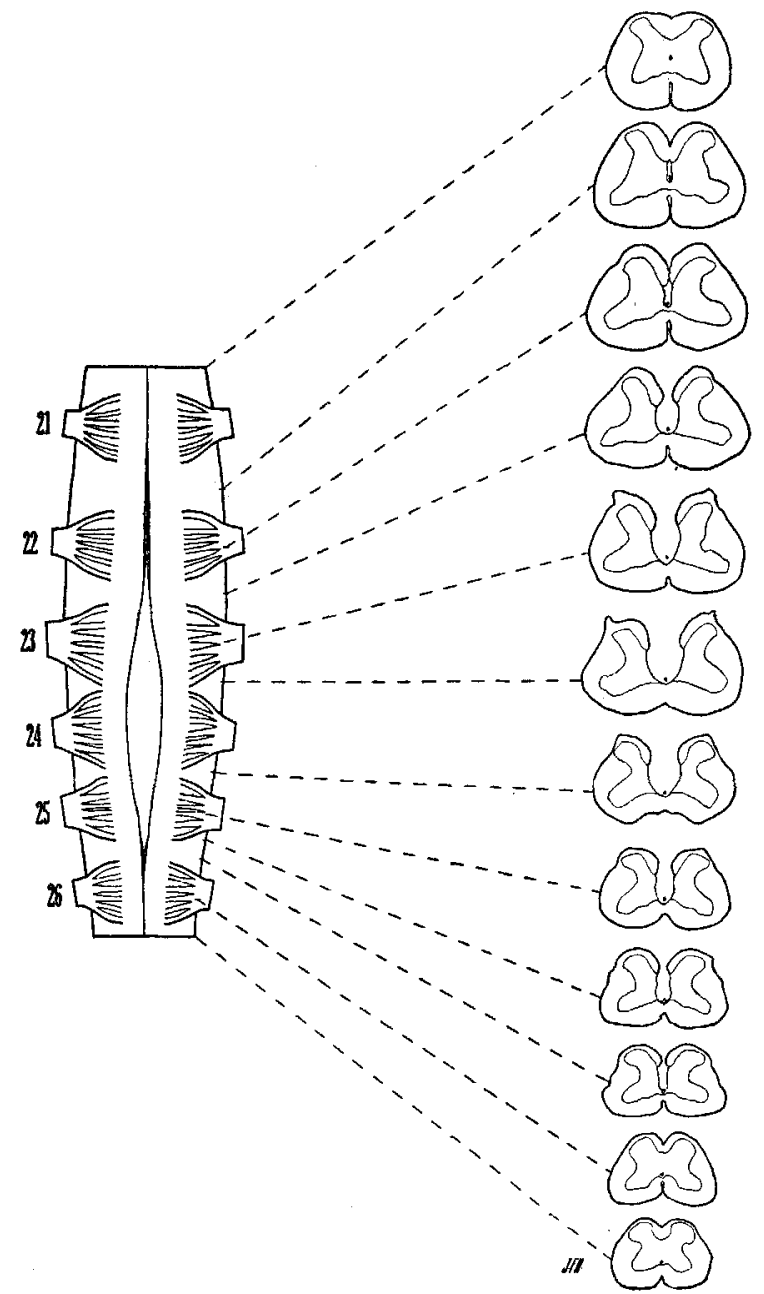

Fig. 3 Sinus rhomboidalis as shown in a dorsal view of the lumbonsacral enlargement of pigeon's spinal cord and outlines of transverse sections at the indicated levels. Neither the contents of the sinus nor the 'accessory lobes' are included in the outlines. The two parts of the figure are drawn to the same scale. The numbers indicate the respective spinal nerves. $\times 5$. 
all of the root levels, as they are present in the sections, was very carefully determined. In the series (E) of longitudinal sections the nerve roots could be readily seen in those sections which were at the correct ventrodorsal level and nerves 12 , 13 and 14 were easily recognized because of their greater size and their nearness to each other (fig. 1). It was possible then to number cephalad from nerve 12 and caudad from nerve 14.

In determining the root levels in the series (B) of cross sections, the first step was to list in order each group of sections in which the emerging rootlets of one nerve could be made out, making use of the thickenings in the marginal paragriseal column (fig. 7, p. 69) to determine the limits of the rootlets of each nerve in the lumbo-sacral and coccygeal regions. On the basis of the distance between successive roots as measured in the number of sections from the last section through one nerve root to the first section through the next nerve root, nerves 11 to 15 were recognized because the four distances between these nerves are distinctly less than the distances between the nerves above and those just below (fig. 1). It was possible then to number cephalad from nerve 11 and caudad from nerve 15.

The numbering thus determined for the nerve roots in the cross section series (B) was checked in three ways. 1) The rhomboid sinus was found to open cephalic to the sections identified as through nerve 23 and to close between the sections identified as through nerves 25 and 26. This position of the rhomboid sinus corresponded to that found on the gross specimens. 2) In series B the so-called 'accessory lobes' were found to be located according to determined root numbers identically to their location in the graphic reconstruction (to be described later, p. 82). 3) The distances between the midpoints of the successive nerve roots from 18 to 31 were measured in the graphic reconstruction and reduced to millimeters. These distances corresponded well with the same distances computed for series $\mathrm{B}$ by multiplying the thickness of each section $(50 \mu)$ by the number of sections between the midpoints of the successive nerves. 


\section{General relations of gray and white matter}

With the exception of the paragriseal nerve cells, to be described later (p. 78), the general relations of the gray and white matter of the pigeon's spinal cord are similar to those in the mammalian spinal cord, namely, a central ' $\mathrm{H}$ ' of gray matter surrounded by white matter as seen in cross sections (figs. 8 to 23). However, in the study of such sections certain interesting facts were noted regarding the changes in the relative size and general shape of the white matter in and near the cervical enlargement which are here briefly mentioned before the detailed consideration of the cell columns is undertaken. These facts, which were not seen as the series of sections was read from beginning to end, became evident when, in analyzing the cell columns, a group of sections, from above the cervical enlargement to below it, were projected on tracing paper and the gray and white matter outlined, the large motor cells in the gray matter being indicated. In superimposing these outlines of successive sections, it was noted that the cross section area of the cord begins to increase, as the enlargement is approached from above, at a level about half way between the emergence of the rootlets of nerves 8 and 9 or over two nerves above the first one contributing to the brachial plexus. The very gradual increase, beginning at about the level indicated, is due to two things: 1) an increase in the gray matter without any great change in its general shape; 2) an increase in the white matter, obviously greater in the dorsal and lateral funiculi than in the ventral funiculi, as shown in figure 4 . This same trend continues to a level at the emergence of the rootlets of nerve 11 where the shape of the gray begins to change so that the changes in the area of the white matter are no longer obvious by simply superimposing the tracings.

However, it was possible by direct superimposition of the tracings, to follow the changes in the area of the dorsal funiculi from above the cervical enlargement to below it, with the following results. As already stated, the area of the dorsal funiculi gradually increases beginning between the emergence 
of nerves 8 and 9 , at which level the area of the dorsal funiculi is found to be approximately the same as the area of these funiculi in the portion of the spinal cord above the enlargement, down to the level of the emergence of nerve 11. From the level of nerve 11 to a level between the emergence of nerves 14 and 15 the area of the dorsal funiculi remains about the same. Then from there to a level about half way between the emergence of nerves 15 and 16 the area gradually decreases to an area about equal to that in the region above the enlargement. This is an indication of the fact that the dorsal funiculi,

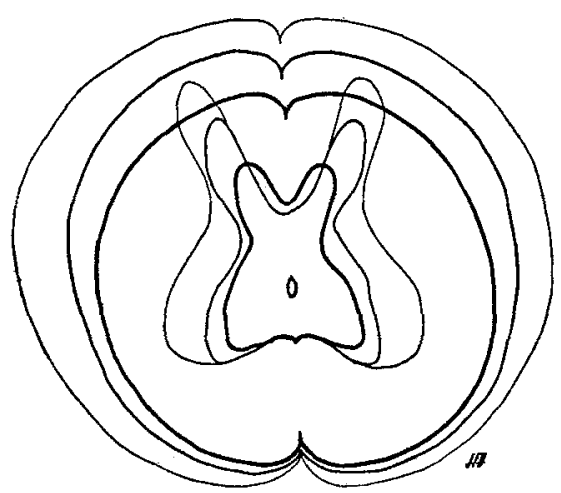

Fig. 4 Outlines of two sections from near the cephalic end of the cervical enlargement superimposed on a typical section from above the enlargement. The darkest outline is of a section between the emergence of nerves 5 and 6 ; the medium outline is of a section just below the emergence of nerve 9 ; the lightest outline is of a section at the emergence of the uppermost rootlets of nerve $11 . \times 22$.

which are made up primarily of proprioceptive fibers, increase in size in the region of the spinal cord at which the nerves of the brachial plexus enter and that they decrease to approximately the size which can be regarded as the standard size for most of the cord just below the brachial plexus and between two and three nerves above this plexus.

It seems possible that these facts may be interpreted as substantiating the accepted conception that in the bird's spinal cord the proprioceptive fibers do not step up for any considerable distance, and as indicating that in the pigeon these fibers probably ascend only two or three nerve levels before terminating and probably descend hardly at all. 
Brouwer ('15, p. 241) studied the percentage of the white matter of the cervical cord occupied by the dorsal funiculi and found this to be in birds about 7 to $8.7 \%$, in snakes $11.9 \%$, and in turtles (Chelone mydas) $13.38 \%$. Ariëns Kappers ('20, pp. 173-174) found it to be $7.7 \%$ in the chicken. Brouwer regarded the relatively small percentage in birds as due to an increase in tecto-spinal and vestibulo-spinal tracts rather than an actual decrease in the dorsal funiculus. Ariëns Kappers, who compared the area of the posterior funiculus to that of the gray matter in the upper cervical cord, regarded this smaller percentage as indicative of an actual decrease in the dorsal funiculi, which agrees with the results obtained in the present study by a different method.

Other changes in the cross section area of the white matter were noted, such as an apparent increase in the ventral funiculi in the thoracic region, but such general impressions were not developed further, since it would have been necessary to introduce an indirect method of comparison, such as the one employed by Streeter ('04, p. 11) to obtain the relative area of the anterolateral funiculi, dorsal funiculi and the gray substance of the spinal cord of ostrich. It was felt that such general considerations could not be regarded as of much value, since too little is known concerning the tracts in the lateral and ventral funiculi of the bird's spinal cord to admit of pertinent deductions.

\section{Cell columns in the central gray matter}

In analyzing the central gray matter of the pigeon's spinal cord there are found to be certain rather distinct columns of cells which, although they do not extend the entire length of the cord and do admit of certain suggested subdivision, when surveyed as a whole can be taken as the basis of the description of the gray matter.

In most cases the literature pertinent to the discussion of the cell columns will be dealt with in connection with the description of the respective column, but a general statement with regard to the literature concerning the medial and lateral 
columns can be undertaken here with advantage, since it applies to both columns. Certain isolated figures of avian spinal cord sections (as, for example, those of Beccari, '22 and Terni, '23) label somatic motor cell groups but no consistent study of these groups throughout an avian cord has come to the attention of the writer, with the exception of Streeter's ('04) description of the cell groups in the spinal cord of the ostrich. Since the publication of his paper studies of various other vertebrate spinal cords have led to a regrouping of the spinal cord motor neurons, rendering the groupings and terminology employed by Streeter difficult to correlate with those of the present account.

Medial column. Of the distinct cell columns recognized in the gray matter, the medial column is the only one which can be said to extend throughout the length of the spinal cord and even this column is much more distinctly a column in the regions of the brachial and lumbo-sacral plexuses. However, it seems permissible to group the ventral horn motor cells, in the regions other than at the major plexuses which must supply trunk musculature, with the distinct medial column of the plexus regions, which, from its probably homology to the ventromedial column of mammalian forms, can be considered as supplying trunk musculature. If that is done, then, as this column is followed from the beginning to the end of the cord, the following facts are observed.

From below nerve 1 (C1) to below nerve 8 (C8), the arrangement remains much the same. The cells of the medial column, which are motor cells, are scattered over the ventral horn (figs. 8 and 9) and admit of no constant subgrouping, although in many single sections distinct medial-lateral or dorsal-ventral groupings or many other subgroupings could be made. Between nerve 8 (C8) and nerve 9 (C9) the ventral horn begins a gradual increase in size, which does not appear to be due to a relative increase in the number of motor cells but to a general increase including an increase in the other cells (secondary cells), fibers and the anterior white commissure. As this increase continues there appears a suggestive 
medial-lateral subgrouping (fig. 10), but it is by no means present in every cross section nor is it more than suggested in the longitudinal sections.

The changes thus described progress to the upper rootlets of nerve 11 (C11), where the cells of the medial column begin to concentrate toward the ventromedial part of the ventral horn (fig. 11). At the level of the middle rootlets of nerve 11 (C11) this concentration has been definitely completed, forming a ventromedial protrusion from the ventral horn which constitutes the arrangement (figs. 12 to 16,25 ) from this level down to the level between nerves 14 (C14) and 15 (T1), where the cells again scatter in the ventral horn (fig. 17). At the level of the rootlets of nerve 12 there is a suggestion in certain sections (fig. 15) of a medial-lateral subgrouping of the medial column. However, this is not constant and in the longitudinal sections it is possible to recognize regions only where a cross section could be projected which would show such subgrouping.

At the level between nerves 15 (T1) and 16 (T2), the ventral horn has decreased in size to a thin, pointed horn characteristic of the thoracic region and the cells of the medial column tend to group toward the tip of the horn (fig. 18).

The changes in the medial column occurring above and below the lumbo-sacral plexus are similar to those described for the brachial plexus region. The general increase in size of the ventral horn begins just above nerve 20 (T6) and continues, with again a suggestive medial-lateral division, to just above nerve 21 (L1) at which level (fig. 19) there is the beginning of the concentration of the cells of the medial column to a ventromedial position, where they remain (figs. 20, 21) in a protrusion from the gray matter which is evident down to the level of nerve 26 (S-C2), where the motor cells again scatter out in the ventral horn, being so placed for the remainder of the length of the cord (fig. 22).

There are distinctly fewer cells in the medial column in the lumbo-sacral plexus region than at the brachial plexus, there being many single cross sections in which no medial column cells are seen. It is interesting to note that even in 
these sections in which the cells are not seen there is a protrusion from the gray matter at the place where they occur in other sections.

In conjunction with the description of the lateral column which is to follow it should be noted that there is an apparent correlation between the concentration of the cells of the medial column to a ventromedial position and the presence of the lateral column. This suggests that it is possible that the cells of the medial column move toward that position so that the neuraxes may course together and not become mingled with the neuraxes of the cells of the lateral column.

The cells of the medial column are large, multipolar cells with a coarse massing of Nissl granules and a distinct nucleolus and tend to appear longer in one direction than in the other. They are on an average smaller than the cells of the lateral column. The silver preparations of embryo chick show the very wide dendritic spread of these neurons (fig. 5). From certain neurons it is possible to trace dendrites into the ventral commissure and other dendrites into the ventral funiculus. The neuraxes of these neurons join with others to pass into the ventral root.

Lateral column. Present only at the regions of the brachial plexus and of the lumbo-sacral plexus, and therefore related to extremity musculature, is the large lateral column. It is difficult to be certain whether the previously described suggestive medial-lateral grouping of the enlarged ventral horn from between nerves 8 (C8) and 9 (C9) to nerve 11 (C11) bears any relation to the lateral column of cells, but an impression was gained from the sections that it probably does not and that the lateral column begins at the upper rootlets of nerve 11 (C11) (fig. 11). The lateral column extends from this level to between nerves 14 (C14) and 15 (T1) in the brachial plexus region. However, it does not have the same appearance throughout this extent and admits of a subgrouping, definite enough to warrant specific description.

The lateral column in this region can be divided into a medial and a lateral part (figs. 12, 13, 15, 25), the medial part having 
the extent given above and the lateral part extending from about the upper rootlets of nerve $12(\mathrm{C} 12)$ to between nerves 13 (C13) and 14 (C14). From their beginnings down to the lower rootlets of nerve 12 (C12), these two parts of the column are quite well separated (fig. 13) but below this level they are not constantly separated (fig. 16, left side of figure), except at the ventral margin of the horn where especially in longitudinal
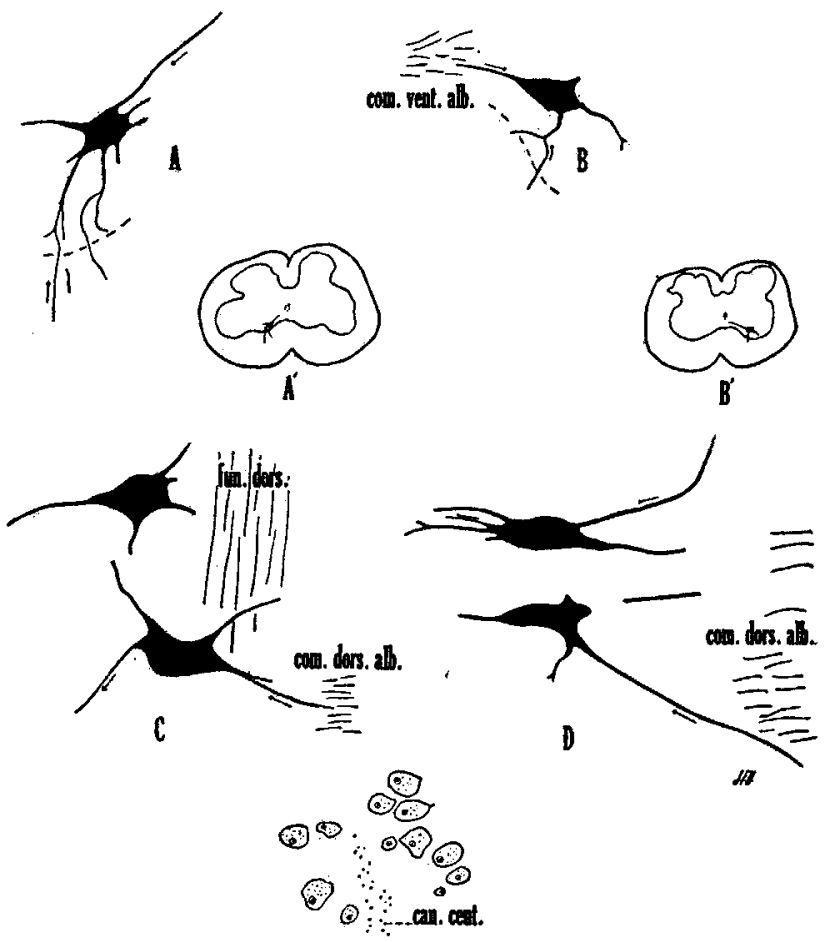

.

Fig. 5 Camera lneida projections of neurons from the pyridine silver preparations of chick embryo spinal cord. $\times 175$. A, ventral horn motor neuron from the medial column in the cervical enlargement (position in key drawing $\mathbf{A}^{\prime}$ ). Note dendrites extending into the ventral funiculus and toward the ventral white commissure. $B$, neuron similar to $A$ in the beginning of the lumbo-sacral enlargement (position in key drawing $\mathbf{B}^{\prime}$ ). $\mathrm{C}$ and $\mathrm{D}$, neurons from the probable largecelled dorsal column, drawn from approximately longitudinal-frontal sections. Note dendrites entering the dorsal white commissure. The neuraxes extend laterally. E, neurons of the preganglionic column (Terni), longitudinal-frontal section. Can. cent., central canal; com. dors. alb., dorsal white commissure; com. vent. alb., ventral white commissure; fun. dors., dorsal funiculus. 
sections a separation is quite constant. Between the region in which there is a distinct medial-lateral subgrouping and the region in which the column appears undivided, the cells of the lateral column are scattered in the area occupied by the column, and cross sections could be selected which would show almost any desired subgrouping; but in following through the serial sections it is found that the gaps which separate these false subgroups in one section are filled in by cells in contiguous sections (figs. 14, 15).

In the medial part of the lateral column, especially above and below where the lateral part of the lateral column is present, there is a suggestive medial-lateral subgrouping (fig. 16) but this is not distinct enough to warrant an attempt at detailed description.

In the lumbo-sacral plexus region the general arrangement of the lateral column is quite similar to that just described for the brachial plexus region, the chief difference being that the subgrouping into a medial and a lateral part is less distinct (fig. 21) except in certain sections near the beginning of the lateral part of the lateral column (fig. 20). The extent of the medial part of the lateral column in this region is from the middle rootlets of nerve 20 (T6) to between nerves 26 (S-C2) and 27 (S-C3) and the extent of the lateral part of the lateral column is from the upper rootlets of nerve 21 (L1) to between nerves 24 (L4) and 25 (S-C1).

The cells of the lateral column are similar to those of the medial column except for their size, which appears to be distinctly greater, and silver preparations indicate that their dendrites pass out into the white matter of the cord as do those of the medial column (Ramón y Cajal, '09). However, it has not been possible in these silver preparations to trace dendrites of any cells of the lateral column into the ventral commissure, although the fact that they can be traced into the region of dispersion of the commissural fibers seems to indicate that they do take that course. The neuraxes enter the rootlets of the ventral horn. 
Column of von Lenhossék. At the beginning of the cord, probably extending from nerve 1 (C1) to between nerves 3 (C3) and 4 (C4) and occupying a position in the lateral part of the gray matter at about the level of the central canal, is a column of cells which in cross sections (fig. 8) are quite similar in size and form to smaller ventral horn motor cells, but are distinctly spindle-shaped in longitudinal sections (fig. 24). These cells possess dark, rod-shaped or oval tigroid granules.
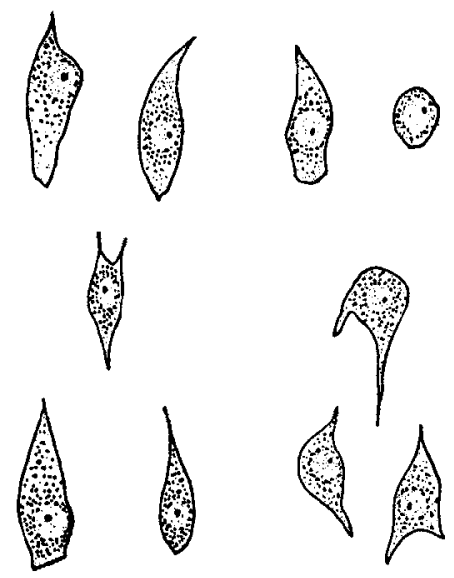

$\mathbf{A}$

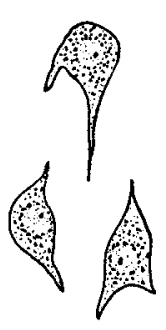

B


D

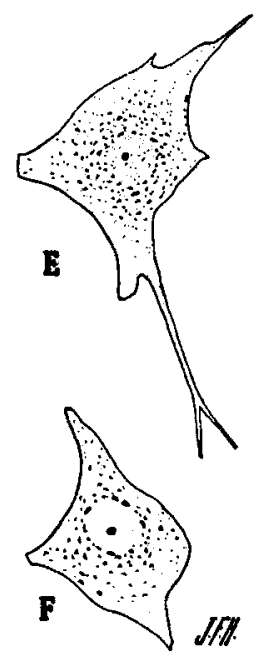

Fig. 6 Camera lucida drawings of representative cells from adult pigeon spinal cord. Toluidin blue. $\times 350$. A to $D$, cells from the marginal paragriseal column as follows: A, longitudinal sections, cervical region; B, longitudinal sections, lumbo-sacral region, Iobi accessori (Lachi); C, cross sections, cervical region; $\mathrm{D}$, longitudinal sections, sacrococcygeal region. $\mathrm{E}, \mathrm{a}$ scattered paragriseal cell from a longitudinal section of the lumbo-sacral region. F, a ventral horn motor cell from the same section as ' $\mathrm{E}$.'

The column is distinctly broader at its beginning, with a tendency for the cells to group, and becomes narrower below, the cells being sparsely scattered below the upper rootlets of nerve 3 (C3).

The series available do not permit the tracing of the neuraxes of these cells, consequently it is at present not possible to state definitely whether or not they constitute the motor component of the dorsal root (usually designated the 'fibers of 
von Lenhossék') described by von Lenhossék (1890) and confirmed by Ramón y Cajal (1890), van Gehuchten (1893), Beccari ('13 and '22) and others. Von Lenhossék (1890, p. 361) stated: "Beim Vogel enthalten also die hinteren Wurzelneinige Bestandteile, die den lateralsten Zellen der Vorderhörner entstammen, in welchen dieselben wahrscheinlich auch ihren entwickelungsgeschichtlichen Ausgangspunkt haben."

Figures and descriptions of observers other than von Lenhossék appear to indicate that such fibers may arise from other than the most lateral ventral horn cells and not from any special cell group. Beccari ('22, fig. 17, p. 158), in a section of the spinal cord of embryonic sparrow, labeled a cell group, 'Colonna motr. dorso-centr.,' indicating the neuraxes of these cells running to the dorsal root as fibers of von Lenhossék. This cell group occupies a central position in the ventral horn, rather than the lateral position emphasized by von Lenhossék, and is on a plane with and ventral to the central canal. Such a cell group, as figured by Beccari, is not consistently present in the series used in this study, but it should be remembered that Beccari's material was embryonic sparrow, whereas the material for this study is adult pigeon. The only group of the cervical region which might be compared with the 'colonna motr. dorso-centr.' is the more lateral and slightly more dorsal cell group, designated column of von Lenhossék (fig. 8) and probably cells of origin of the fibers of von Lenhossék. Such fibers have been regarded as the submammalian representatives of the spinal portion of the accessory nerve in mammals. This column of cells occupies a position consistent with that interpretation.

Preganglionic column (Terni). Terni ('23) described in embryonic and adult avian material, which included sections of pigeon and chicken spinal cord, a column of cells, 'nucleo radicolare motore profondo (pregangliare)," primarily lateral to the central canal, later dorsal to it and near the midline, which he regarded as forming the cells of origin of the sympathetic or thoraco-lumbar portion of the autonomic nervous system. He found that this column extends from 
slightly above his T1 (which appears to be $\mathrm{C} 14$ of the present account) to slightly below L2 (of both accounts) and contributes preganglionic fibers through the ventral roots to the sympathetic ganglia.

In the present study a corresponding cell column is clearly evident in the longitudinal sections of the adult pigeon cord (fig. 26), where it consists of rather small, multipolar to spindle-shaped cells with Nissl granules compatible with a preganglionic designation. Only an occasional cell of this column showed impregnation in the silver material, but where such impregnation occurred the dendrites appear to be smaller and to have less spread than those of the ventral horn neurons. Two characteristics of the cells seen, possibly deserve mention: 1) the eccentric position of the nucleus in many cases; 2) the presence of evident pericellular baskets. These cells occupy a position comparable to that described by Terni but lie even closer to the midline, so that at certain levels it is difficult to separate them into two columns. In the pigeon's cord the upper limits of this column fall between nerves 13 (C13) and 14 (C14), the lower limits between nerves 21 (L1) and 22 (L2). The extent is in essential agreement with that figured by Terni ('23, p. 447, fig. 4). Except at its cephalic and caudal limits, the column shows little variation in thickness or cell number throughout its extent. The cross sections document the findings in the longitudinal sections but this plane is less favorable for determining the exact limits of the column. In this connection it is to be noted that cells of a similar type and possibly of like functional significance are found scattered ventral and lateral to the column.

In the sacral cord Terni described a cell column comparable in position and general relations to that figured by him as a preganglionic column in the thoracic cord. He was unable to determine definitely its functional significance but favored the interpretation that it is the sacral representative of the parasympathetic or cranio-sacral portion of the autonomic nervous system. His figure ('23, p. 447, fig. 4) indicates that this column extends from the closure of the rhomboid sinus 
caudally for seven nerve roots. In the longitudinal sections used in the present study of the pigeon cord, a cell group in general similar in position and cell type to the preganglionic column (Terni) of the thoraco-lumbar cord, but less distinctly organized, could be traced from nerve 26 (S-C2) to approximately nerve 30 (S-C6). This column is much less evident in cross section material, although traces of it can be seen between nerves $26(\mathrm{~S}-\mathrm{C} 2)$ and $28(\mathrm{~S}-\mathrm{C} 4)$ as indicated by the letter $\mathrm{x}$ on figure 22 .

Large-celled dorsal column. Included within the central gray of the spinal cord are many neurons which do not contribute to nerve roots but which give rise to secondary fiber paths. Among such is a definite cell column composed of large multipolar cells, with relatively fine Nissl granules, situated in and near the base of the dorsal horn (figs. 11 to 16, 18 to 21 , 27 ) and termed the large-celled dorsal column in this account. Its exact limits are difficult to determine. The major extent of the column is from just below nerve 10 (C10) to below nerve 27 (S-C3). Cephalic to nerve 10 (C10) the column is continued by somewhat smaller and more scattered, but otherwise similar cells, to just below nerve 9 (C9); caudal to nerve 27 (S-C3) occasional cells of similar type and position are found which are scarcely numerous enough to constitute a column but which are recognized in the longitudinal sections as far caudal as nerve 34 (S-C10).

This column is not equally well developed at all levels. It is large from below nerve 10 (C10) through nerve 13 (C13) and from below nerve 20 (T6) through nerve 24 (L4). Between the levels of emergence of nerve 13 (C13) and nerve 20 (T6) the column is small and the cells scattered, there being many cross sections in which either no cell or only one or two cells of this type are found (see particularly figs. 17, 18). It is obvious then that the column is developed best in the regions of the cord enlargements.

It is not possible to homologize directly the Clarke cells, and the dorsal cells of Streeter's ('04, p. 20, fig. 6) account with the column described here. Streeter's suggestion that 
cells of this type found in the lumbo-sacral region should be regarded as Clarke cells on the basis of mammalian homologies does not seem justified in view of the extent and relations of the column as seen in the pigeon material. Undoubtedly the commissural cells described by various observers (Ramón y Cajal, 1890 , '09, and others) in bird cord may fall in part within this column but the entity of the large-celled dorsal column has not been recognized by such observers.

A study of pyridine silver preparations of embryonic chick shows certain interesting relations of the processes of cells probably of this column. The cell body of such a neuron (fig. 5) may send one dendrite through the dorsal commissure to the contralateral dorsal gray, another dendrite to the homolateral dorsal gray and its neuraxis toward the lateral funiculus. Obviously such a cell serves as a coordinating mechanism, interrelating impulses from both sides of the body. The dendrites of another type of neuron (fig. 5) found in this column spread out through the homolateral dorsal gray, while the neuraxis turns medially to decussate in the dorsal commissure. In these preparations similar cells are seen in and near the midline of the dorsal commissure region. Since in the adult pigeon material no large cells are seen in this position, it is suggested that these cells become incorporated later in the large-celled dorsal column. It is interesting to note that large neurons are also found among the fibers of the ventral commissure in the embryonic material.

Other cells in the central gray matter. There are numerous cells all through the central gray matter other than those included in the described columns. Such cells are scattered in all parts of the gray not occupied by the columns and between the cells making up the columns, and in general are secondary or association cells. The dorsal horn particularly is composed of cells of this secondary character. In the regions of the enlargements these horns are relatively long and narrow but in the rest of the cervical cord they are stubby, in the thoracic region they are club-shaped and in the sacro-coccygeal, below the enlargement, decrease gradually to scarcely more 
than bulges on the central gray. These changes are comprehended best by following them through figures 8 to 22 . In addition to these variations in form, there are variations in the amount of gray dorsal to the central canal, which appear greater than they actually are because of the great differences in the appearance and amount of the surrounding gray and white matter. The large amount of gray dorsal to the central canal forms a striking contrast to the small amount of gray in this region in man. The substantia gelatonisa forms a cap over the rest of the dorsal horn throughout the cord, although it varies in thickness in the different regions. Keenan ('29) studied the phylogenetic development of the substantia gelatinosa in various vertebrates including birds and noted certain variations in this substance in the avian forms studied. No grouping of these secondary cells either in the dorsal or the ventral horn, other than those considered, is apparent, so that no further description will be given except to mention that their increase in number contributes to the enlargements.

At the cephalic end of the longitudinal sections, at the probable level of nerve 1 (C1), there is a grouping of the cells of the ventral horn which it was not possible to interpret since it is obviously related to the medulla and sections through the continuity of the medulla and spinal cord would be necessary to ascertain its meaning. This region has been studied particularly by Beccari ('13, '22) in reptiles and birds.

\section{Peripheral gray matter-Paragriseal nerve cells}

Although the superficial examination of the spinal cord gives one the conception of a central ' $H$ ' of gray matter surrounded by white matter, it is incorrect to consider the nerve cells as confined to the so-called gray portion of the cord. As early as 1873 it was shown by Beisso that in the ox nerve cells are found in the white substance near the gray. The observations of Pick, apparently on dog, and of Schiefferdecker on human material also recognized this fact. The above references are taken from Sherrington's 1890 paper on "Outlying nerve-cells in the mammalian spinal cord," in which he reviewed the literature and described his own observations on that subject. 

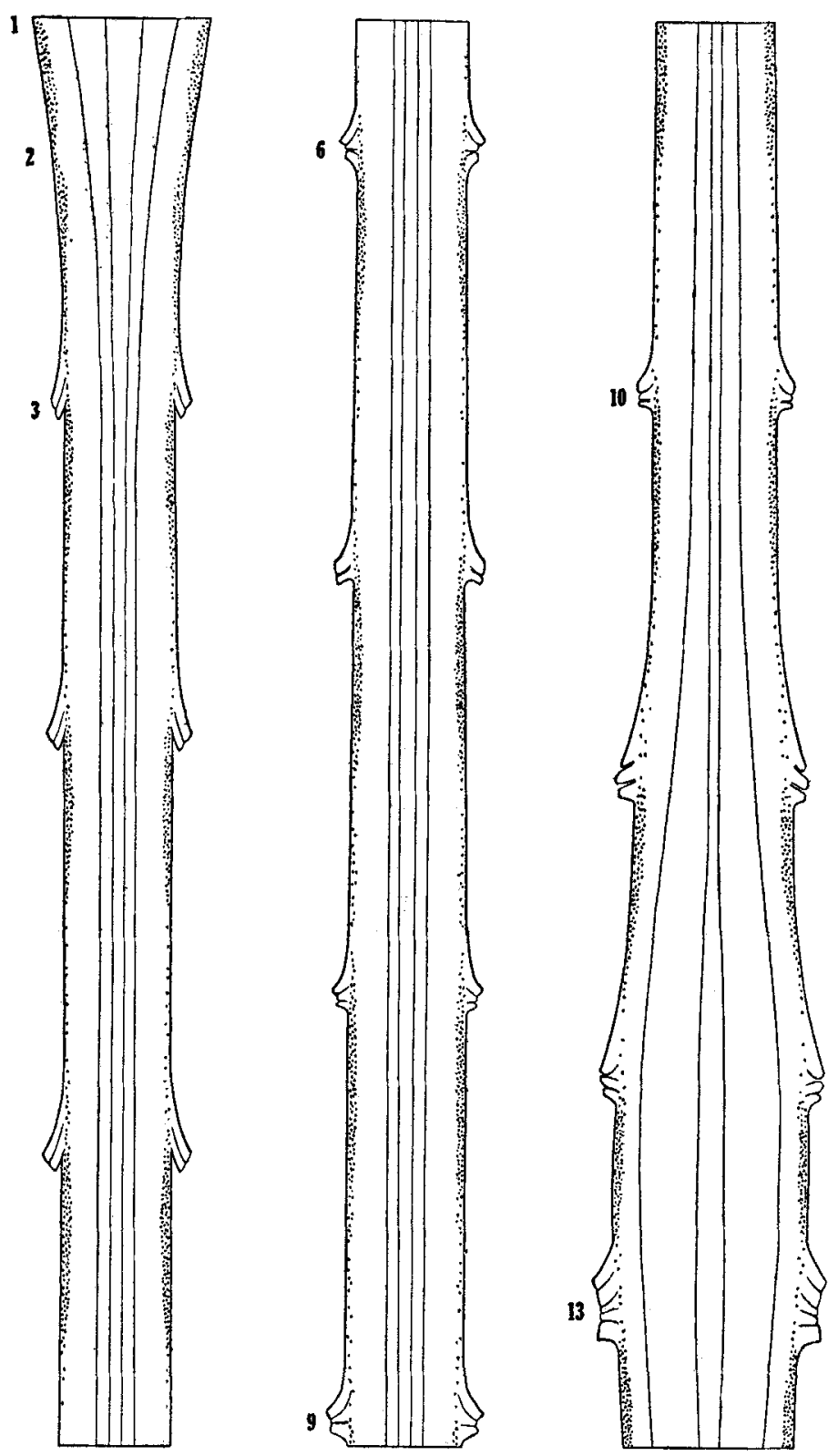

Fig. 7 Representation of the 'graphic reconstruction' described on page 82 . The dotted areas show the exact extent and shape of the marginal paragriseal column as it appears in the reconstruction. There are many more dots (cells) on the original than could be shown here. The dispersed dots appearing from 

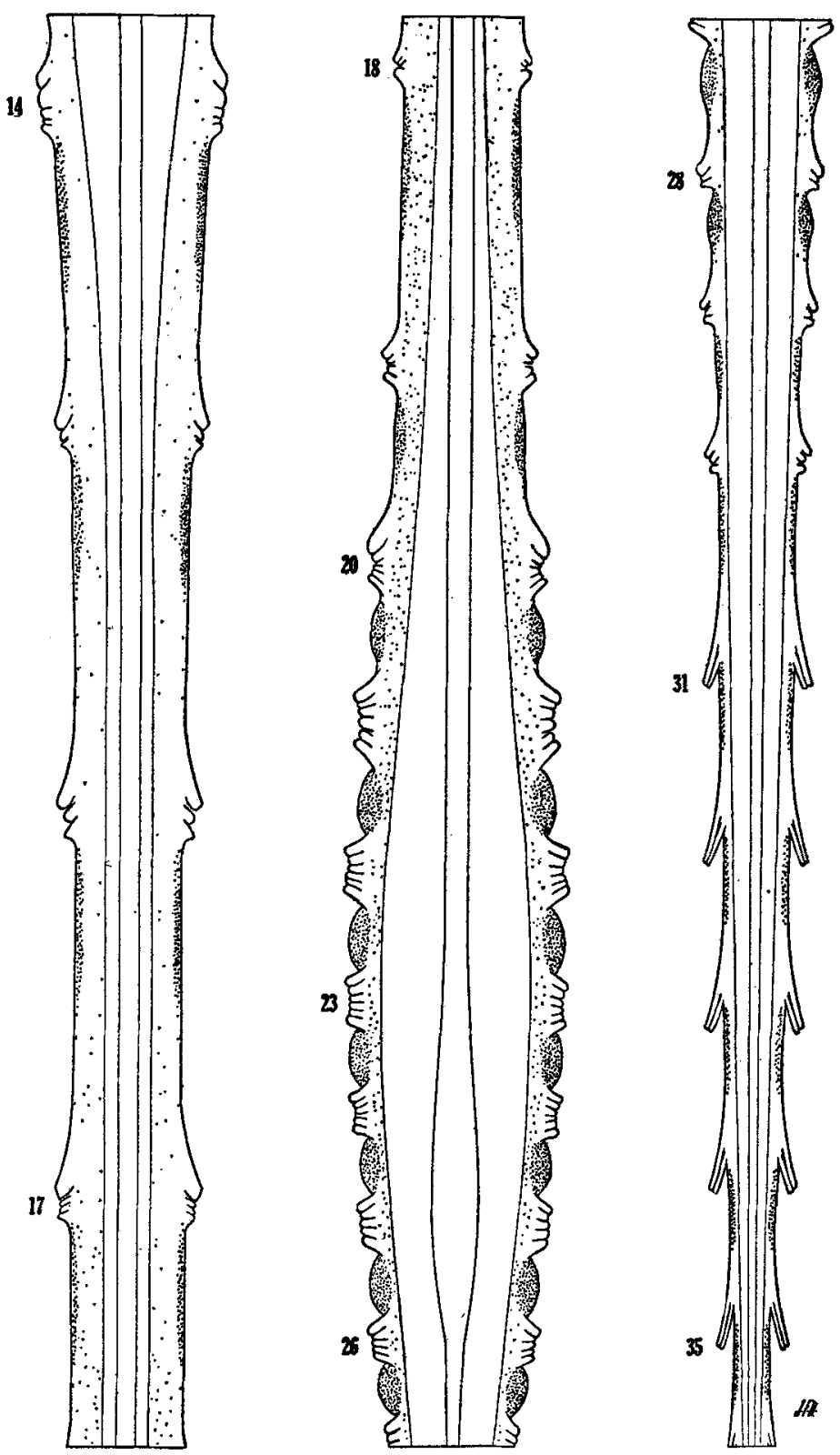

nerve 14 to nerve 28 represent scattered paragriseal cells. The light lines indicate the approximate boundaries of the gray matter of the widest part of the ventral horn. The numbers indicate specific nerve roots. These figures are $a \times 6$ reduction of the reconstruction and $\times 7$ magnification of the sections. 
Gaskell (1885), the first observer to describe outlying cells at the periphery of the cord, gave a short description of a discontinuous group of nerve cells in a ventrolateral position at the periphery of alligator spinal cord. He found these cells in groups between the emergence of the spinal nerves and because of this segmental arrangement and the character of the cells he regarded them as parts of the posterior root ganglia. However, as von Kölliker pointed out later, Gaskell (1889) appeared to have changed to the view that these peripheral ganglia are motor in function when he spoke of them in crocodiles and birds (giving a figure of a section of the cord of about an 8-day chick) in a short paper on cranial nerves.

\section{LIST OF ABBREVIATIONS USED IN FIGURES 8 TO 27}

can. cent., central canal

cel. paragr. dif., seattered paragriseal cells

col, dors. magnocel., large-celled dorsal column

col. lat., lateral column

col. lat.p. lat., lateral part of lateral column

col. lat. p. med., medial part of lateral column

col. v. Len., column or nucleus of von Lenhossék

col. med., medial column

col. paragr.marg., marginal paragrisea] column col. pregang. ('Terni), "nucleo radicolare motore profundo (pregangliare)"' (Terni, '23)

com. dors. alb., dorsal white commissure com. vent. alb., ventral white commissure corn. dors., dorsal horn corn. vent., ventral horn fun. dors., dorsal funiculus fun. lat., lateral funiculus fun. vent., ventral funiculus lob. ace. (Lachi), lobus accessorus (Lachi)

sept. dors., dorsal septum

sin. rhomb., rhomboid sinus sub. gel., substantia gelatinosa

Figures 8 to 22 and 24 to 27 are projection drawings of sections of pigeon's spinal cord. Toluidin blue. $\times 22$.

Fig. 8 Cross section at the lower rootlets of nerve 3 (C3). The major regions of the spinal cord are indicated on this figure for the series.

Fig. 9 Cross section half way between the rootlets of nerves 7 (C7) and 8 (C8). The motor cells of the ventral horn are seen to be scattered through the horn. These are considered as belonging to the medial column.

Fig. 10 Cross section half way between the rootlets of nerves 9 (C9) and 10 (C10). At the tip of the ventral horn on the left side of the figure, a suggestive medial-lateral grouping of the ventral horn cells is seen.

Fig. 11 Cross section at the upper rootlets of nerve 11 (C11). The lateral column is just appearing. 

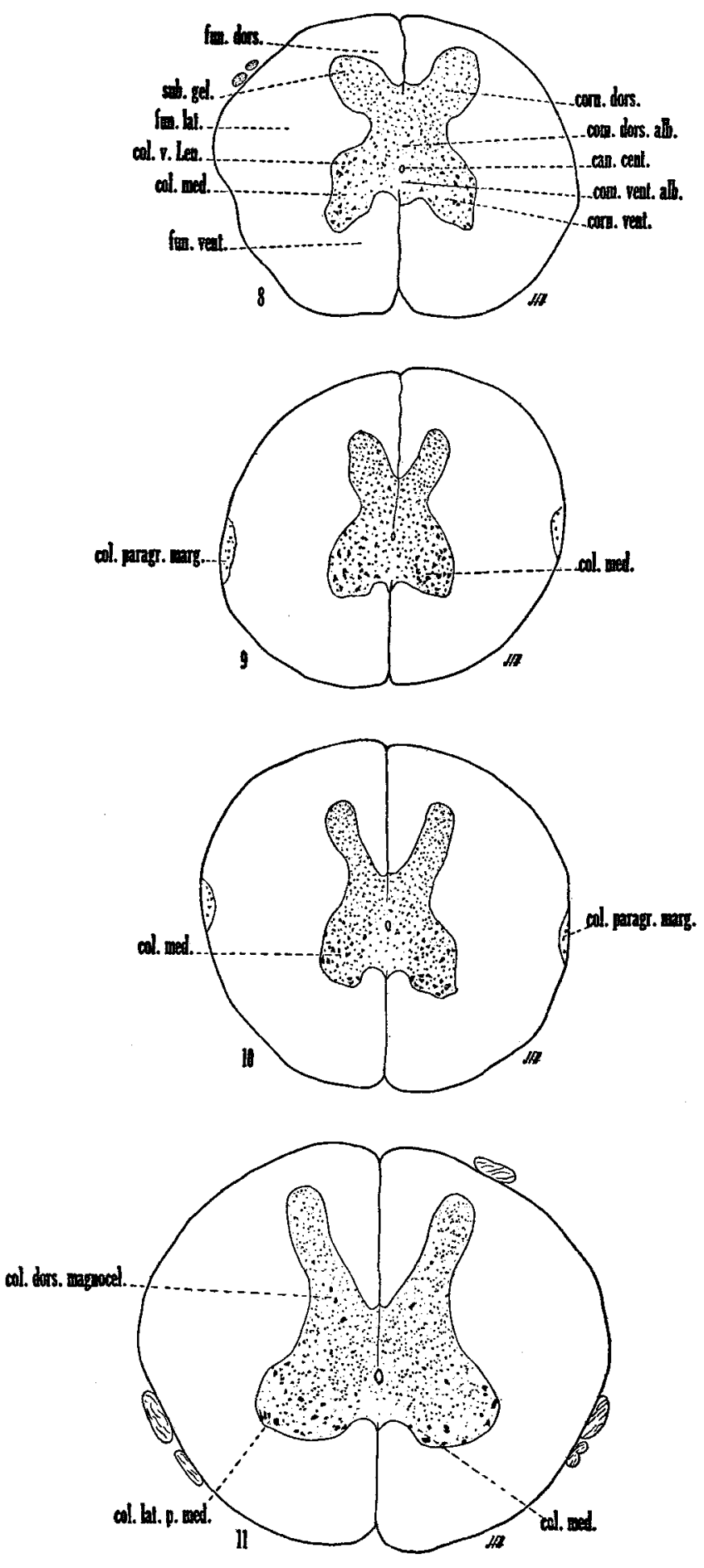

71 
Pilade Lachi (1889) was the next observer to describe peripheral cells, the description being given under the name 'lobi accessori.' He spoke of five to eight pairs of accessory lobes on the lumbar enlargement of birds located at the attachment of the denticulate ligament and corresponding with the limits of the metameres. These lobes or masses he described as being made up principally of a gelatinous substance similar to that in the rhomboid sinus and containing nerve cells of which he gave a minute description, concluding that they resemble ventral horn cells. Similar cells in the midst of the nerve fibers at the angle of union of the ventral and lateral funiculi were also described by him and were considered as representing a link between the ventral horn and the accessory lobes. In a later paper Lachi ('02) reviewed the above observation and stated that the structures described by von Kölliker ('02) were merely those to which he had previously called attention.

In his discussion of the neurology of birds, Hans Gadow (1891) described a peripheral group of nerve cells under the heading "Gray matter of the spinal cord." He stated that they lie close to the lateral thickening of the pia, even bulging out from the cord, that the mass varies metamerically, being most developed in the sacral region, that the cells are embedded in a clear meshwork which contains no medullated fibers and that no out-going fibers were demonstrated. He was uncertain as to the significance of these cells.

Ramón y Cajal (1893, p. 63) referred to observations on the cervical cord of a 16-day chick which showed fusiform nerve cells in the external zone of the lateral funiculus, sagittally oriented and with processes coming in relation with peripheral collaterals of the white substance of the anterolateral column.

Fig. 12 Cross section just above rootlets of nerve 12 (C12). It is apparent that the cells in the lateral column on the left side of the figure would admit of several subgroupings.

Fig. 13 Cross section at the upper rootlets of nerve 12 (C12). A distinct medial and lateral subgrouping in the lateral column is shown.

Fig. 14 Cross section a little above middle rootlets of nerve 12 (C12). It would be difficult to subgroup the lateral column in this section. 

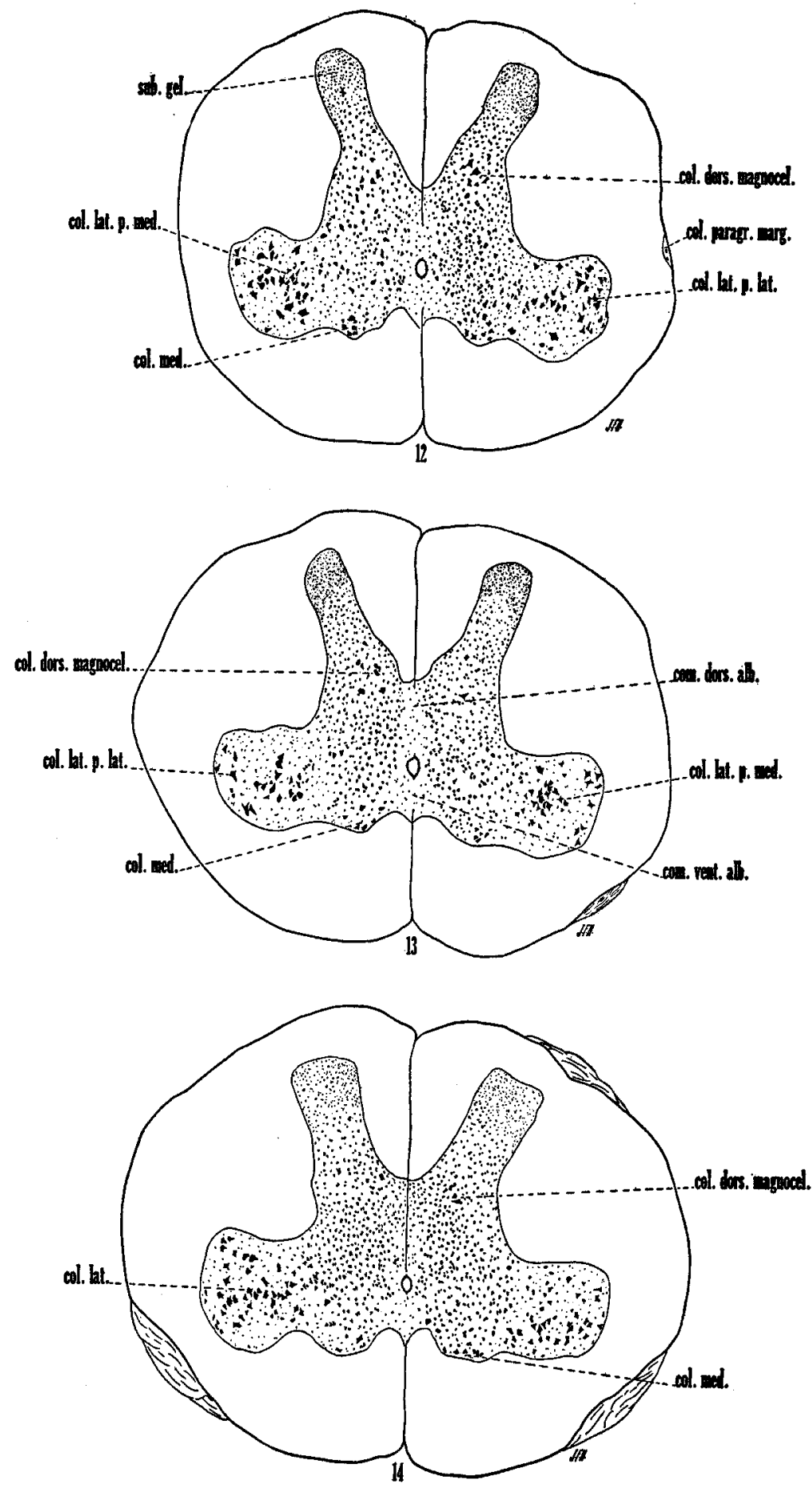
In silver-impregnated sections of 9-day chick spinal cord, von Lenhossék $(1894,1895)$ noted cells in the boundary zone between the ventral and the lateral funiculus with processes passing through the ventral commissure into the ventral funiculus of the opposite side. He described in detail several types into which these cells could be grouped but he considered them all as dislocated commissural cells, a view concurred in by Ramón y Cajal (1899, p. 504; '09). He further stated that he believed these to be the same cells which Ramón y Cajal (1893) had seen in the chick and probably the same cells as those pictured by von Kölliker (1893, p. 192, fig. 441) in the pigeon.

In his comprehensive work on meninges, Guisseppe Sterzi ('01, p. 1211, fig. 4, Tav. XII) pictured a lobus accessorus and said there are eight such on each side in the lumbo-sacral region of chick.

A most complete work on the outlying cells in the spinal cord was done on birds and reptiles by von Kölliker ('02), who named the outlying cells he described 'Hofmann's Nuclei' after his technician P. Hofmann who called his attention to these groups of cells. His observations on quail, pigeon and both embryonic and adult chicken preparations can be briefly reviewed in the following manner. The Hofmann nuclei are superficial, just beneath the pia and just dorsal to the attachment of the denticulate ligament, have a definite segmental arrangement, and can be divided into two groups, the Hofmann'sche Grosskerne and Kleinkerne or the major and minor nuclei of Hofmann. The major nuclei are found in the

Fig. 15 Cross section just five sections from figure 14. A triple dorsal-ventral subgrouping could be made in the lateral column on the left side of the figure but it should be noted that these cells in this figure would fill in to some extent the gaps in the lateral column on the left side of figure 14. The medial column on the left side of this figure shows a suggestive medial-lateral subgrouping.

Fig. 16 Gross section at the uppermost rootlets of nerve 13 (C13). This figure shows a suggestive medial-lateral subgrouping of the medial part of the lateral column on the right side of the figure.

Fig. 17 Cross section at the upper rootlets of nerve 15 (T1). Cells of the medial column are again seen, becoming scattered in the ventral horn. The preganglionic cell column of Terni should be noted. 

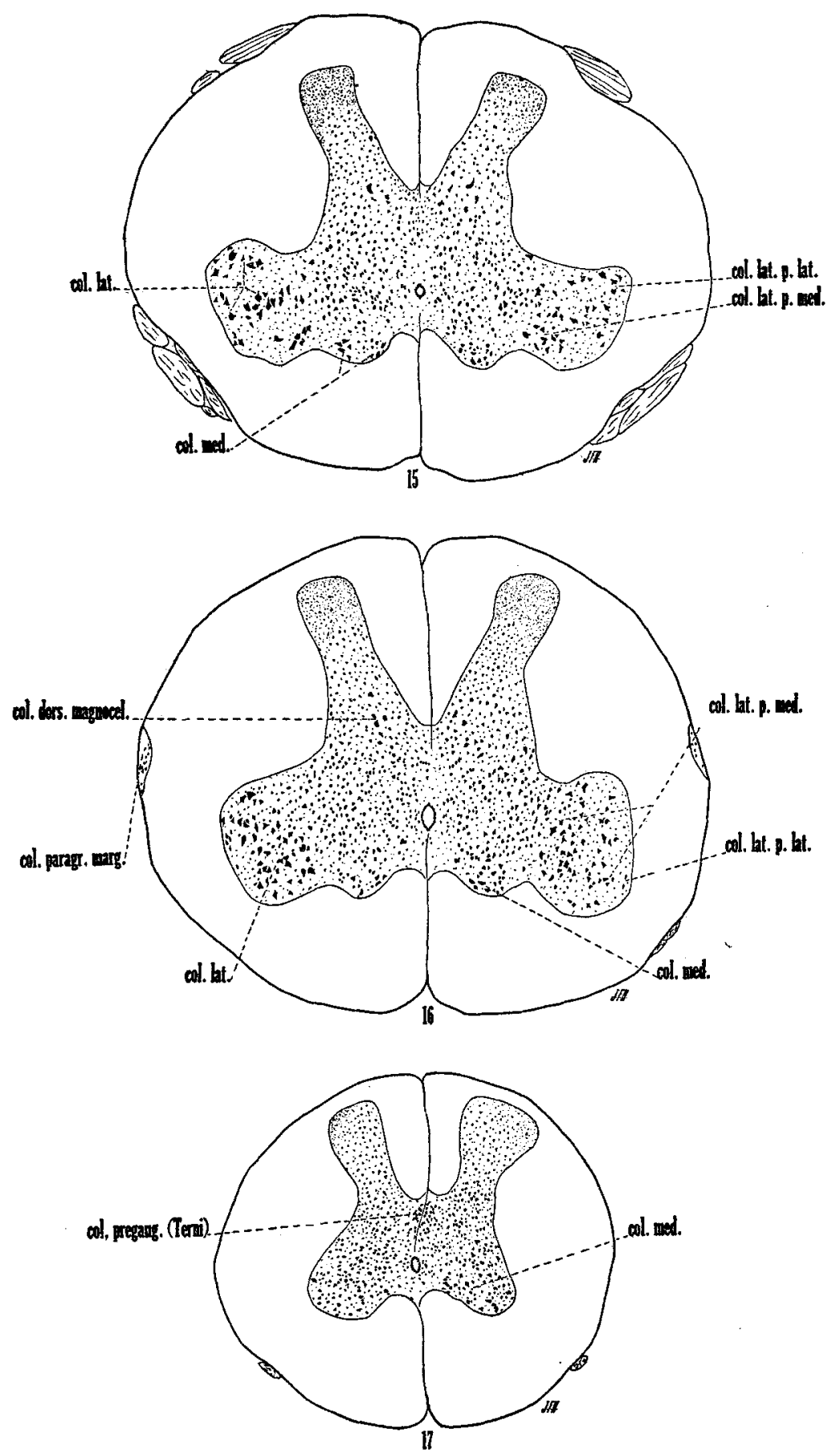
lumbo-sacral region and bulge out from the cord. They have a framework of a rather loose glial web in which are embedded multipolar cells similar to ventral horn motor cells but measuring $10-16-27 \mu$ in contrast to $20-30-45 \mu$ for the ventral horn cells. The minor nuclei, found in the cervical, thoracic and lower sacral regions, are made up of cells, some of which are very similar to those in the major nuclei and some of which are smaller. There is an increase in glial substance in the minor nuclei but they do not bulge from the cord. Von Kölliker stated that the Hofmann nuclei are embryologically derived from the cell mass of the ventral horn but he suggested three possibilities as to their function: 1 ) that they are detached cells of origin for motor fibers; 2) that they are preganglionic cells ; 3 ) that they are ventral commissural cells. In this paper von Kölliker referred to Brandis' (1893) article on the central nervous system of the bird in which are figures of a section of the cervical cord of Picus viridis, of Anser canadensis and of Regulus cristatus, all of which show an area relatively free from fibers in the anterolateral angle of the cord. These areas von Kölliker thought represented his Hofmann nuclei.

Sterzi ('04) described peripheral cells in reptiles which he considered as motor elements.

Outlying cells were next discussed by Streeter ('04) in his complete description of the spinal cord of ostrich. Following more or less von Kölliker's classification, he grouped the outlying cells in ostrich cord into major marginal nuclei, minor marginal nuclei and scattered cells. He described the major nuclei as visible macroscopically, one pair at the level of each sulcus transversus from the thirtieth to the thirty-sixth segment, located just dorsal to the ligamentum denticulatum and made up of a glial framework in which are myelinated neuraxes and multipolar cells about one-fourth to one-sixth as large as ventral horn cells but otherwise similar to them. The minor nuclei he described much as von Kölliker had except that he spoke of their cells as small and not definitely multipolar. He found the scattered cells to be like ventral horn cells and to be present in the ventrolateral funiculi near the major 

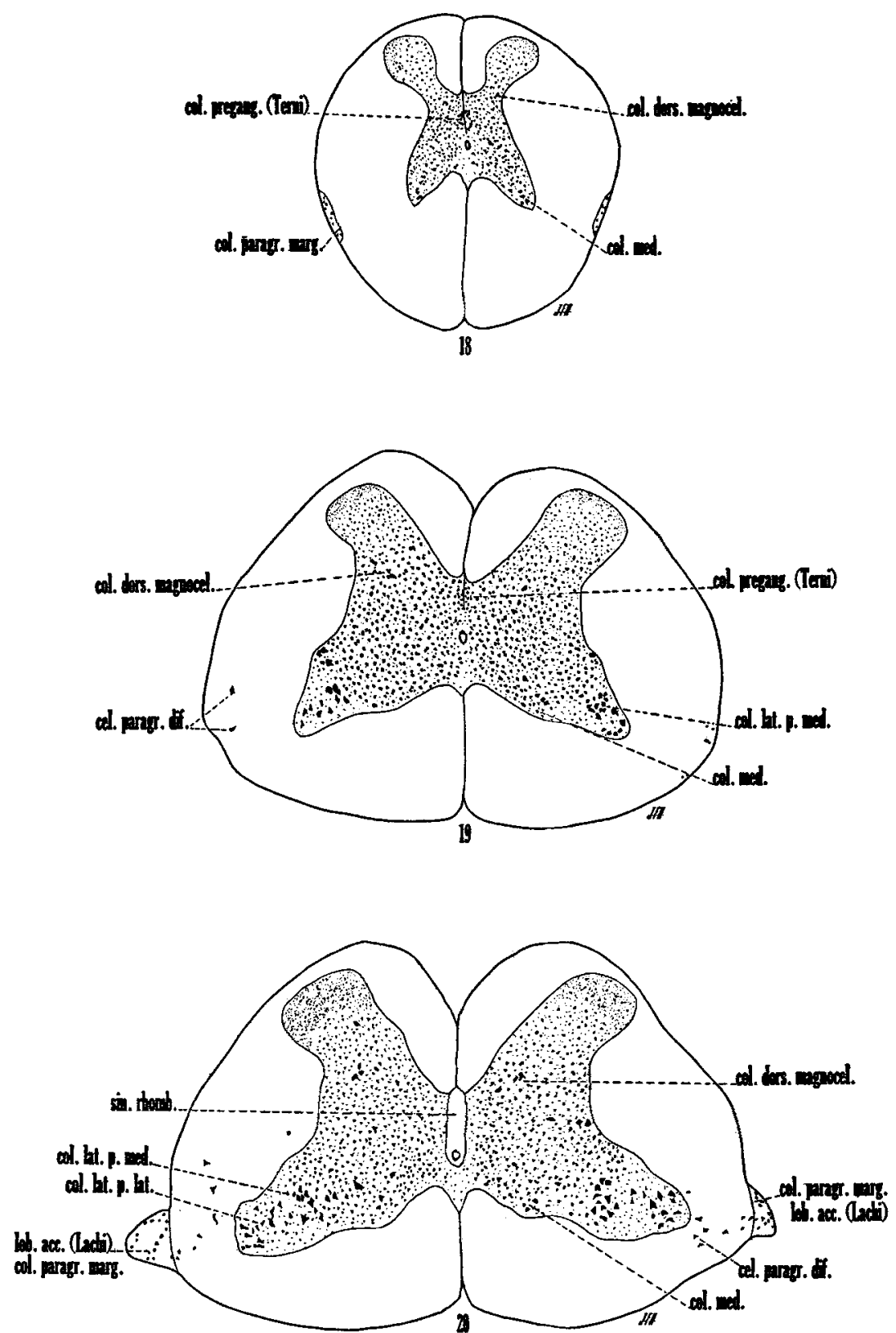

Fig. 18 Cross section half way between the rootlets of nerves 16 (T2) and 17 (T3).

Fig. 19 Cross section just above rootlets of nerve 21 (L1). This section is near the beginning of the lumbosacral enlargement.

Fig. 20 Cross section half way between nerves 21 (LI) and 22 (L2). Formation of lobi accessori (Lachi) by the marginal paragriseal column is seen. 
marginal nuclei. No discussion of the possible functions of the outlying cells was given in his account.

Krause ('22) described briefly the Hofmann nuclei of von Kölliker in birds and reptiles and Poljak ('24) studied them in Chiroptera.

The most recent mention of outlying cells found was that by Terni ('26) who described these cells in reptiles and birds. He reported ten (sometimes eleven) major marginal nuclei in chick embryos, nine or ten in the pigeon and eight in the swallow, goose and duck. In the larger major nuclei he described several hundred cells, the neuraxes of which could be traced only through the ventral commissure to the most medial part of the opposite ventral funiculus. Since no fibers could be found ending on the cells in the major nuclei, he suggested that these cells may show a spontaneous origin of impulse.

Marginal paragriseal column. In the examination of the sections of pigeon's spinal cord, many nerve cell bodies were seen outside of the central gray matter and these are designated in this account 'paragriseal nerve cells.' The paragriseal cells near the surface of the cord and therefore called 'marginal paragriseal cells' are noted throughout the entire length of the cord (figs. 9,10,12,16,18, 20, 21, 22), on both sides, forming a column of cells here named the 'marginal paragriseal column' which is practically an unbroken column but has very definite segmental thickenings (fig. 7). That is, the cells are much more numerous in the spaces between the emergence of the rootlets of consecutive nerves than at their

Fig. 21 Cross section half way between nerves 23 (L3) and 24 (L4). It should be noted that the scattered paragriseal eells are of two types, one like ventral horn cells and the other like the cells of the marginal paragriseal column. No attempt is made to indicate the histological structure of the contents of the rhomboid sinus.

Fig. 22 Cross section half way between rootlets of nerves 31 (S-C7) and 32 (S-C8). Medial column again is scattered through the ventral horn. $X$, the probable sacral representative of the craniosacral preganglionic column and 'nucleo paracentrale sacrale' (Terni, '23, p. 480).

Fig. 23 Diagrammatic transverse section of pigeon spinal cord showing all of the cell columms as though found at one level. The figure legends indicate the extent of each cell column as stated in nerve levels. (More complete detail as to the extent of the cell columns is given in table 3, p. 87). 

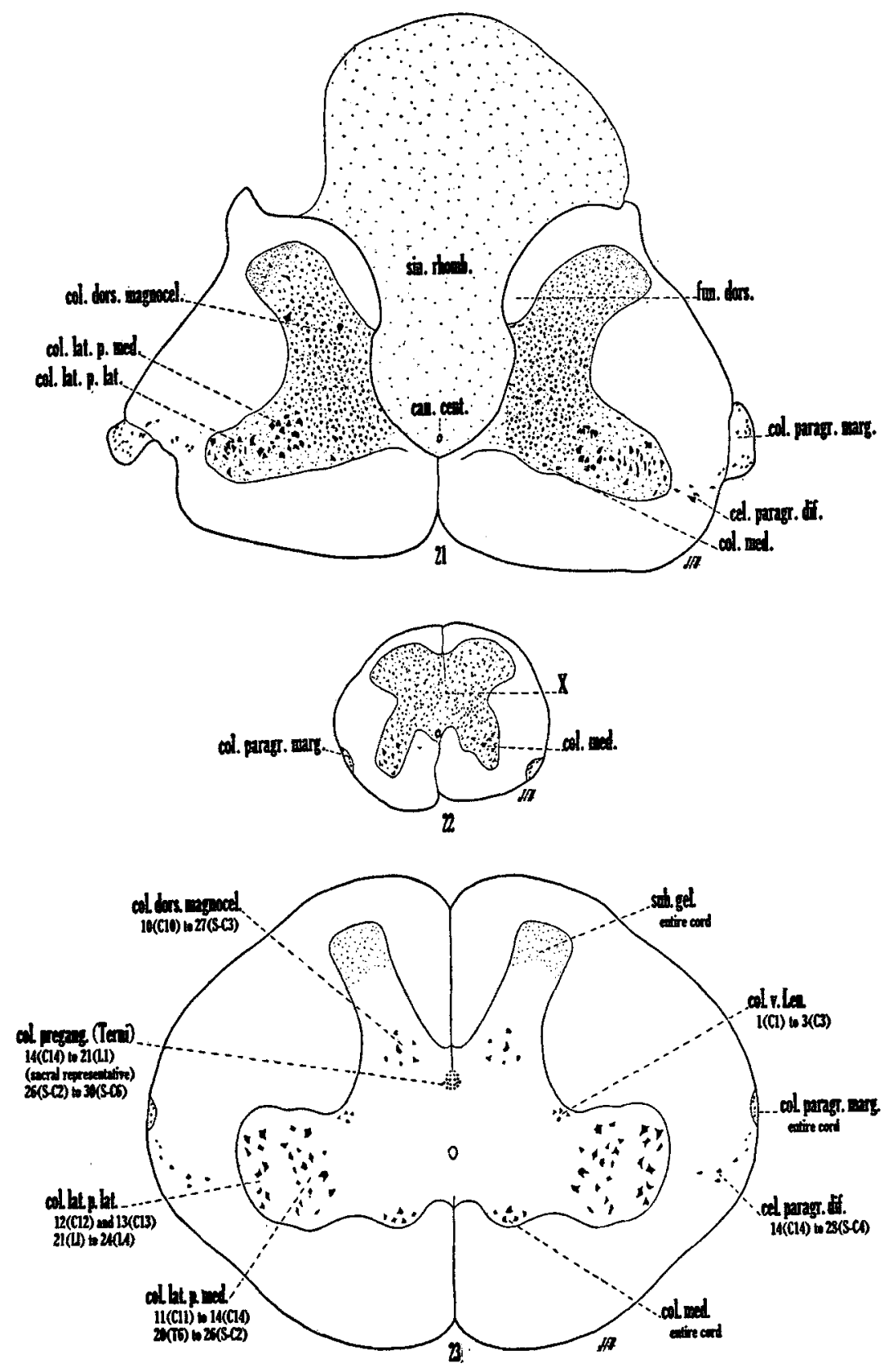
emergence. In passing from the cephalic to the caudal end of the cord, there is a decrease to almost zero in the number of cells at the levels of emerging rootlets.

In the cervical, thoracic and coccygeal regions (figs. 9, 10, $12,16,18,22)$, the marginal paragriseal cells are located in the lateral funiculus at its outer margin somewhere near its junction with the ventral funiculus. In the region of the lumbo-sacral plexus, the marginal paragriseal cells together with a loose glial framework in which they are embedded form protrusions from the cord (figs. 20,21), one of which entirely occupies the distance between the emergence of each two consecutive nerves (fig. 7). There is no doubt that these protrusions are the structures which are described by Lachi (1889) and others as 'lobi accessori,' by von Kölliker ('02) as 'Hofmann'sche Grosskerne' and by Streeter ('04) as 'major marginal nuclei.' The thickenings of the marginal paragriseal column in the cervical, thoracic and coccygeal regions are the structures described by von Kölliker as 'Hofmann'sche Kleinkerne' and by Streeter as 'minor marginal nuclei.'

The marginal paragriseal cells as seen in the cervical, thoracic and coccygeal regions are ovoid, about 20 to $30 \mu$ in length and 7 to $11 \mu$ in width and are quite regularly longitudinally oriented. Their nuclei are spherical and occupy most of the width of the cell and their processes are seen coming off from each end of the cell (fig. 6,A). Certain of the cells as seen in the lumbo-sacral portion of the marginal paragriseal column correspond exactly to the above description (fig. 6, B) and many cells appear to be this type of cell cut at different angles, a few appearing as irregular multipolar cells somewhat similar to ventral horn cells but less than half their size and lighter staining. The fact that in the lumbo-sacral region the cells are in a loose glial framework instead of 'lined up' by the fibers of the lateral funiculus as they are in the other regions can probably account to a large extent for the impression of a difference in the cells which has been described or implied in earlier discussions. 
can, cont.

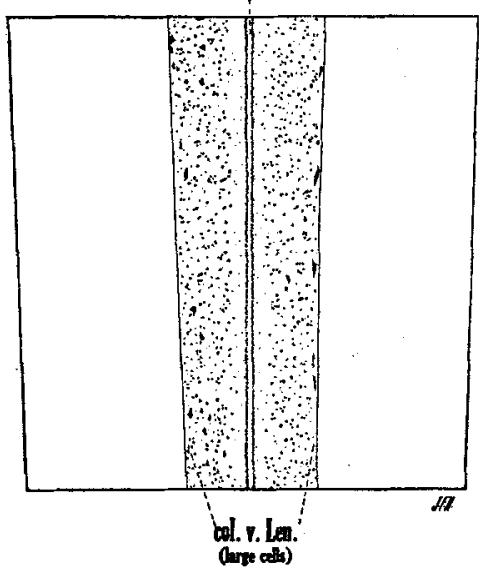

24

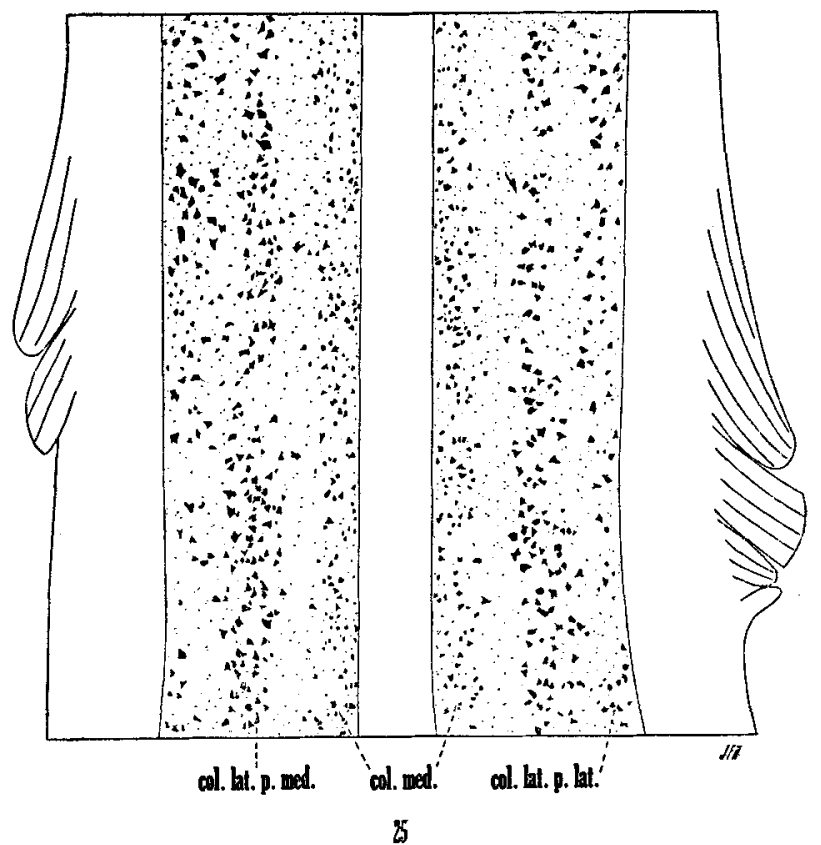

Fig. 24 Longitudinal-frontal section just caudal to nerve 3 (C3), at the central canal, indicating the column or nucleus of von Lenhossék.

Fig. 25 Longitudinal-frontal section through the level of nerve 12 (C12) at the ventral portion of the ventral horn, indicating the cell columns of the ventral horn.

THE JOURNAL OF COMPARATIVE NEUROLOGY, VOL. 65 
The marginal paragriseal cells which previous accounts have separated into major and minor marginal nuclei have been considered here as forming a marginal paragriseal column for three reasons. First, as pointed out above, the cells are believed to be of the same type throughout the length of the cord. Secondly, at both the upper and lower ends of the lumbosacral region there is a gradual transition from the situation in that region to the one in the rest of the cord. That is, between nerves 20 (T6) and 21 (L1) the marginal cells with a very small amount of glial framework form a slight protrusion from the cord. Between nerves 21 (L1) and 22 (L2) the protrusion is greater in size. Then between each two consecutive nerves from nerve 22 (L2) to nerve 27 (S-C3) there is a full-sized protrusion. Between nerves 27 (S-C3) and 28 (S-C4) there is a slightly smaller protrusion and the one between nerves 28 (S-C4) and 29 (S-C5) is distinctly smaller. Between nerves 19 (T5) and 20 (T6) and between nerves 29 (S-C5) and 30 (S-C6) it is difficult to decide whether or not there is any protrusion. The third reason for describing the marginal paragriseal cells as making up a column is that one sees them as a definite column in what may be called a graphic reconstruction (fig. 7), which was made in the following manner from series $\mathrm{E}$ of longitudinal sections of pigeon cord. Each section of the series was drawn with the aid of a projection apparatus indicating the white and gray in outline and placing in its exact position each nerve cell lying outside of the central gray. The drawings were made on a high grade tracing paper, at a magnification of 40 and every cell was checked twice with the microscope. The cells thus plotted were then all gathered onto a single drawing from near the center of the series. This was accomplished by tracing the cells in four consecutive drawings onto the fifth in sequence. That is, every fifth drawing was superimposed on each of the four preceding drawings while the cells were traced onto it. The tracings thus made were used to accumulate all of the cells in a similar manner onto a single drawing which then constituted a graphic reconstruction of the paragriseal cells. Of 




a

Fig. 26 Longitudinal-frontal section at the level of nerve 15 (T1), six $30 \mu$ sections dorsal to the central canal, indicating the preganglionic column of Terni.

Fig. 27 Longitudinal-frontal section just cephalic to nerve 11 (C11), two $30 \mu$ sections dorsal to the point of separation of the dorsal horns, indicating the largecelled dorsal column. 
course, there were many cells which occupied the same relative position so that every cell could not be separately represented in the reconstruction, but the extent, distribution, and grouping of the cells is excellently shown.

As to the function of the cells of the marginal paragriseal column, it can only be said that so far there is no evidence which does not fit in with the view that they are dislocated ventral commissural cells. This concept was demonstrated by von Lenhossék (1894), and mentioned as possible by von Kölliker ('02).

Scattered paragriseal cells. In addition to the marginal paragriseal column, there are 'scattered paragriseal cells' (figs. 19, 20, 21) which are distributed in the white matter lateral and ventrolateral to the ventral horn, scattered irregularly from the margin of the gray almost out to the surface of the cord. These cells begin to appear very sparsely about at the caudal end of the cervical region and increase gradually in number down to the lumbo-sacral plexus region where they are most numerous. They disappear near the caudal end of this region.

Many of the scattered paragriseal cells are much like the ventral horn multipolar cells, the only apparent difference being that they appear on the average a little smaller. There are, however, certain ones (fig. 6, E, F) which are as large as the largest ventral horn cells, so that it seems logical to consider them as dislocated cells of that type. Other scattered paragriseal cells, especially certain cells close to the accessory lobes, are unquestionably of the type constituting the marginal paragriseal column (fig. 21).

It is thus seen that the nerve cells lying outside of the central gray in the pigeon's spinal cord may be grouped into marginal paragriseal cells, which form a column with segmental increases - the marginal paragriseal column - at the surface of the lateral funiculus near its junction with the ventral funiculus, and which are probably dislocated ventral commissural cells, and scattered paragriseal cells found in the thoracic and lumbo-sacral regions which are in part like 
the marginal paragriseal cells but are chiefly dislocated ventral horn cells.

\section{Contents of the rhomboid sinus}

It is not the purpose of the present account to enter into a detailed consideration of the rhomboid sinus. The contents of the sinus are semitransparent and according to Terni ('24) contain vacuolated cells containing glycogen. Streeter ('04) and Terni ('26) regarded this substance as of neuroglial origin; Hansen-Pruss ('23) and Ariëns Kappers ('24) believed it to be of leptomeningeal origin. The continuation of the central canal through the whole sinus (fig. 21) eliminates any possibility of comparing it with the fourth ventricle. Medullated fibers have been described as passing through the substance above the central canal by Hansen-Pruss ('23) and Ariëns Kappers ('24) and are evident in the silver preparations studied in the present research.

\section{DISCUSSION AND CONCLUSIONS}

A review of the literature on avian spinal cord indicated the prime necessity for the establishment of a standard enumeration of the spinal nerves of the pigeon and a standard allocation of these nerves to the customarily described regions, in order that a basis for descriptions of microscopic findings could be used which would permit of a comparison of the results here given with those which may be recorded in future work. The major plexuses were used in determining the allocation of the spinal nerves to regions, since most of the changes in the internal configurations of the gray of the spinal cord, in different species, would be correlated with the plexuses, and, in this connection, it is interesting to note that the make-up of the major plexuses in the pigeon corresponds closely with that in man.

The completeness of the analysis of the gray matter into cell columns owes much to the availability of serial sections in both longitudinal-frontal and transverse planes. Having sections in both planes is not only valuable because of the opportunity it affords to check the results obtained in the sections 
cut in one plane against those obtained in the sections cut in the other, but also because one plane may be particularly favorable for the demonstration of certain relations. For example, the demonstration of the column arrangement of cells is convineing only in longitudinal sections (figs. 24 to 27). The study of the general configuration of the gray and establishment of comparisons with the figures in the literature are furthered by the use of cross sections. It is self-evident that exact and dependable determinations of the extent of cell columns and the evaluation of groupings apparent in any given section necessitate complete series. It is equally obvious that practically none of the studies on avian spinal cord have utilized complete series.

For the sake of brevity the essential information regarding the major cell columns described in this account has been tabulated in table 3 (see also fig. 23). The substantia gelatinosa has not been included in the table because the results obtained are purely confirmatory of results in the literature (Keenan, '29, and others).

The position, extent and general cell character of the medial column justify homologizing it with the medial or ventromedial column of reptiles and mammals which comparative and experimental evidence indicates is concerned with the innervation of axial or trunk musculature. While chosen levels suggest a medial and lateral division of this column, no consistent subgrouping into two parts can be made.

The position and cell character of the lateral column, correlated with its presence only at the enlargements, suggest its probable homology to similarly located cell columns in the ventral horns of certain reptiles (alligators and turtles but not snakes) and of mammals. The subdivisions of the lateral column in pigeon, while not constant throughout the extent of either enlargement, are definitely medial and lateral in character. It seems probable that the medial part of the lateral column is homologous to the mammalian ventrolateral column or nucleus and the lateral part of the lateral column to the mammalian dorsolateral column or nucleus. The various sub- 


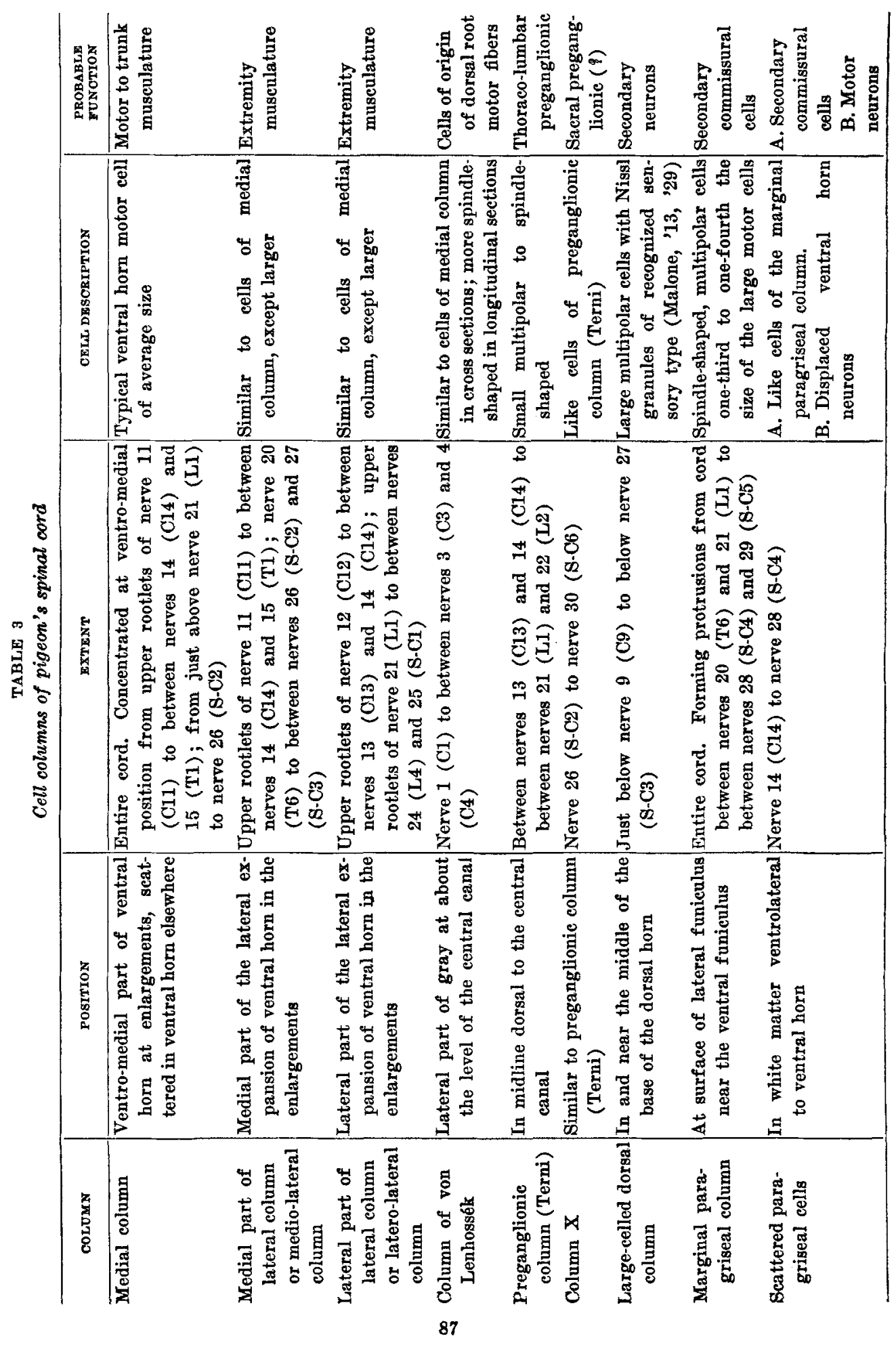


divisions of the lateral column shown in the literature are obviously not based on studies of serial sections.

In the pigeon's cord the cells designated the column of von Lenhossék occupy a position in accord with its interpretation as homologous to the spinal nucleus of the accessory nerve in mammals. Final judgment in regard to this interpretation and the correlation with descriptions in the literature (Beccari, '22) must be reserved until preparations showing the course of the neuraxes of these cells are available.

The preganglionic column of Terni and its probable sacral representative are particularly demonstrable in the longitudinal sections (fig. 26). Attention is called to certain cell characteristics-namely, the eccentric position of the nuclei and the presence of pericellular baskets which together with the character of their Nissl granules (Malone, '13 and '29) suggest their assignment to the general visceral efferent group.

The secondary neurons grouped in the large-celled dorsal column are particularly numerous at the regions of the enlargements. This suggests a correlation with the increase in the number of sensory fibers entering, due to the brachial and lumbo-sacral plexuses. The distribution of this column precludes its being considered as the direct homologue of Clarke's nucleus as has been supposed (Streeter, '04), although the possibility of its giving rise to spino-cerebellar fibers is not precluded.

In this account there are two contributions to the facts regarding marginal paragriseal cells. 1) These cells form a column present throughout the cord, although almost interrupted at the emergence of each spinal ventral root. It is suggested that these cells, the neuraxes of which probably cross in the ventral commissure, are concentrated between the emergence of the nerve roots in order that their neuraxes need not cross through the roots, but may pursue an unimpeded course to the commissure. 2) These cells are alike throughout the column, suggesting a similarity in function for all of them. This fact is of importance in view of the division into major and minor nuclei current in the literature. 
In conclusion it may be stated that the cellular arrangement in the spinal cord of the pigeon, and probably of avian spinal cord in general, presents a distinct resemblance to the cellular arrangement of the spinal cord gray of mammals, though it is to be recognized that on the whole the avian cord presents a more primitive differentiation.

\section{LITERATURE CITED}

ARIËNS KApPERs, C. U. 1920 Anatomie des Nervensystems. Vol. 1. Haarlem, E. F. Bohn.

1924 The lumbo-sacral sinus in the spinal cord of birds and its histological constituents. Psychiat. en neurol. Bl., Amsterdam, vol. 28, pp. 87-97.

Beccari, N. 1913 Sulla spettanza delle fibre del Lenhossék al sistema del nervo accessorio $\theta$ contributo alla morfolgia di questo nervo (Osservazioni in Lacerta muralis). Arch. ital. di anat. e di embriol., vol. 11, pp. 299-351.

1922 Studi comparativi sulla struttura del rombencefalo. I. Nervi spino-occipitali e nervo ipoglosso. II. Centri tegmentali. Arch. ital. di anat. e di embriol., vol. 19, pp. 122-292.

Brandis, F. 1893 Untersuchungen über das Gehirn der Vögel. Arch. f. mikr. Anat., Bd. 41, S. 168-194. Tafel XIII, figs.1, 2a, 4 (quoted by von Kölliker).

Brouwer, B. 1915 Die biologische Bedeutung der Dermatomerie. Folia Neurobiol., vol. 9, pp. 225-336.

GaDOW, H. 1891 Dr. H. G. Bronn's Klassen und Ordnungen des Thierreichs. Leipzig, C. F. Winter.

GaskenLL, W. H. 1885 On a segmental group of ganglion cells in the spinal cord of the alligator. J. Physiol., vol. 7. Proc. Physiol, Soc., no. IV, pp. $X X I X$ and $X X X$.

1889 Cranial nerves. J. Physiol., vol. 10, pp. 191-210.

vaN GEHUChTEN, A. 1893 Les éléments nerveux moteurs des racines postérieures. Anat. Anz., Bd. 8, S. 215-223.

Hansen-Pruss, O. C. 1923 Meninges of birds, with a consideration of the sinus rhomboidalis. J. Comp. Neur., vol. 36, pp. 193-217.

Huber, G. C. 1927 New method of fixation and staining of the central nervous system for purpose of study of cytoarchitecture. Contributions to Medical Science, dedicated to Aldred Scott Warthin, pp. 1-12.

HUBER, G. C. AND S. R. GUILD 1913 Observations on the peripheral distribution of the nervus terminalis in Mammalia. Anat. Rec., vol. 7, pp. 253-272.

HoxLEY, T. H. 1872 Manual of anatomy of vertebrate animals. New York, D. Appleton and Co.

KEENAN, E. 1929 The phylogenetic development of the substantia gelatinosa Rolandi. Ir. Amphibians, reptiles and birds. Kon. Akad. v. Wetensch. te Amsterdam, Proc. sect. sc., vol. 32, pp. 299-310. 
KINGSLEY, J. S. 1925 The vertebrate skeleton from the developmental standpoint. Philadelphia, P. Blakiston's Son and Co.

voN KölLikgR, A. 1893 Handbuch der Gewebelehre des Mensehen. Bd. 2. Leipzig. (Referred to oy von Lenhossék, 1895.)

1902 Über die oberflächlichen Nervenkerne im Marke der Vögel und Reptilien. Zeits. f. wiss. Zool., Bd. 72, S. 126-180.

1902 Weitere Beobachtungen über die Hofmann'schen Kerne am Mark der Vögel. Anat. Anz., Bd. 21, S. 81-84.

KraUse, R. 1922 Mikroskopische Anatomie der Wirbeltiere. Bd. II. Berlin and Leipzig, De Gruyter and Co.

LACHI, P. 1889 Aleune particolarita anatomiche del rigonfiamento sacrale nel midollo degli uecello. Atti. d. soc. tose. di se. nat., vol, 10, pp. 268-295. 1902 Intorno ai nuelei di Hofmann-Kölliker o lobi accessori del midollo spinale degli ueceli. Anat. Anz., Bd. 21, 8. 7-8.

voN LENHOsstek, M. 1890 Über Nervenfasern in den hinteren Wurzeln, welehe aus dem Vorderhorn entspringen. Anat. Anz., Bd. 5, 8. 360-362.

1894 Beiträge zur Histologie des Nervensystems und der Sinnesorgane. Wiesbaden, J. F. Bergmann.

1895 Der feinere Bau des Nervensystems im Lichte nenester Forschungen. Berlin, H. Kornfeld.

MaLone, E. F. 1913 The nueleus cardiacus vagi and the three distinct types of nerve cells which innervate the three different types of muscle. Am. J. Anat., vol. 15, pp. 121-129.

1929 Functional signifieance of histologic eharacter in preganglionic viseeral neurones. Areh. Neurol. and Psychiat., vol. 32, p. 295.

Martin, H. N. AND W. A. MOALE 1888 Handbook of vertebrate dissection. II. How to dissect a bird. New York, Macmillan Co.

Martin, R. 1904 Die vergleichende Osteologie der Columbiformes unter besonderer Berücksichtigung von Didunculus strigirostris. Universität Basel.

Packard, A. S. 1879 Zoology. New York, Henry Holt and Co.

PAPEz, J. W. 1929 Comparative neurology. New York, Thomas Y. Crowell Co.

PARKER, T. J. 1884 A course of instruction in zootomy. London, Macmillan Co.

Parker, T. J. AND W. A. Haswell 1910 A textbook of zoology. London, Macmillan Co.

PoLJAK, S. 1924 Die Struktureigentümlichkeiten des Rüekenmarks bei dem Chiropteren. Zeits. f. d. ges. Anat., Abt. 1; Zeits. f. Anat. u. Entwicklungsgesch., Bd. 74, S. 509-576.

RAMón Y CAJAL, S. 1890 A quelle époque apparaissent les expansions des eellules nerveuses de la moelle épinière du poulet? Anat. Anz., Bd. 5, S. 609613 ; s. 631-639.

1893 Nuevo concepto de la histologia de los centros nerviosos. Barcelona, Henrich y Co.

1899 Textura del sistemo nervioso del hombre y de los vertebratos. Madrid, N. Moya.

1909 Histologie du système nervenx de l'homme et des vertébrés.

Paris, A. Maloine.

REYnolds, S. H. 1913 Vertebrate skeleton. Cambridge University Press. 
Shrarington, C. S. 1890 On out-lying nerve-cells in the mammalian spinal cord. Phil. Tr. Roy. Soc., London, ser. B, pp. 33-48.

ShuFenot, R. W. 1901 Osteology of pigeons (Columbae). J. Morph., vol. 17, pp. 487-514.

STERzI, G. 1901 Ricerche intorno all'anatomia comparata ed all-ontogenesi delle meningi. Prima Parte, Meningi midollari. Atti d. R. Ist. Veneto di sc., lett. ed arti, vol. 60 , p. 1211 .

1904 I gruppi cellulari periferichi della midolli spinali di Rettili. Atti d. Soc. tose. di se. nat. Mem., vol. 20, pp. 242-273.

STREETFR, G. L. 1904 The strueture of the spinal cord of the ostrich. Am, J. Anat., vol. 3, pp. 1-27.

TERNI, T. 1923 Ricerche anatomiche sul sistema nervoso autonomo degli necelli. Arch. ital. di anat. e di embriol., vol. 20, pp. 433-510.

1924 Ricerche sulla cosidetta sostanza gelatinosa del midollo lumbosacrale degli uccelli. Arch. ital. di anat. e di embriol., vol. 21, pp. 55-86. 1926 Sui nuclei marginali del midollo spinale del Sauropsidi. Arch. ital. di anat. e di embriol., vol. 23, pp. 610-628. 